\title{
Preliminary identification of potential markets for off-grid electrification: Tool development and a case study of Ghana
}

Benoit Descoqs ${ }^{1}$ and Subhes Bhattacharyya ${ }^{2, *}$

${ }^{1}$ Polytech Lille, Lille, France

Email: Benoit.descoqs@gmail.com

${ }^{2}$ Subhes Bhattacharyya

Professor of Energy Economics and Policy,

IESD, De Montfort University

Leicester LE1 9BH, UK

Email: subhesb@dmu.ac.uk; subhesb@gmail.com

* corresponding author

This is the accepted version of the manuscript. The version of record of the manuscript has been published and is available in International Journal of Sustainable Energy on 22.07.2016. It is available at http://www.tandfonline.com/doi/full/10.1080/14786451.2016.1210145. 


\section{Abstract}

With more than 1 billion people lacking access to electricity in the world, ensuring universal access to electricity by 2030 remains a major challenge which cannot be left to the government initiatives alone. Access to local information and identification of potential areas for investment can be a challenge for investors. This paper provides a tool for preliminary assessment of potential markets for off-grid electrification in developing countries and applies this to Ghana to demonstrate its applicability. A multi-criteria approach is used to rank the districts according to the overall potential and the best markets and least favourable areas for investment are identified. The tool offers flexibility to include new inputs to the analysis and the factor weights can be adjusted as appropriate. The case study shows that the tool can effectively identify potential areas from a list of candidates and offers support to analysts.

Keywords: spreadsheet tool; ranking; electricity access; developing countries; Ghana 


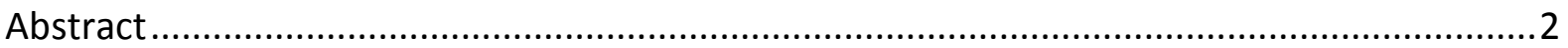

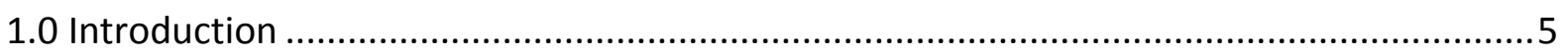

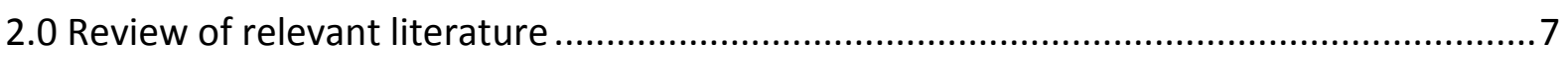

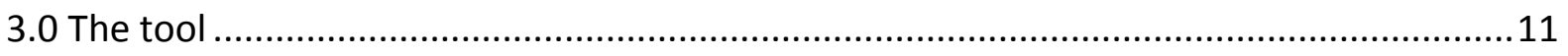

4.0 Identification of potential markets in Ghana ................................................................13

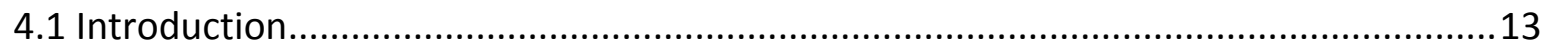

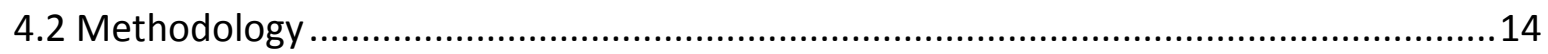

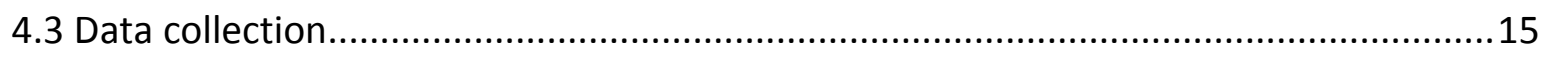

The study has relied on the Population and Housing Census of 2010 [16] that offers a large set of information. Clearly, more recent information would make the analysis better but in the absence of any other exhaustive source of information, the census

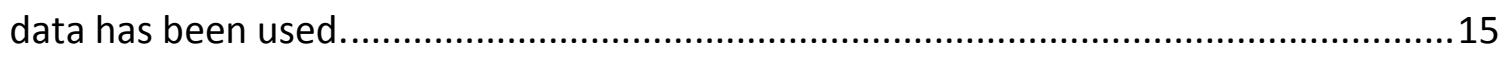

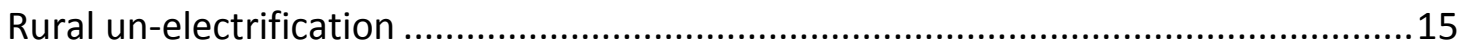

Rate of mobile phone users/internet facility users/desktop computers or laptop

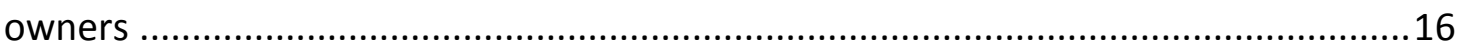

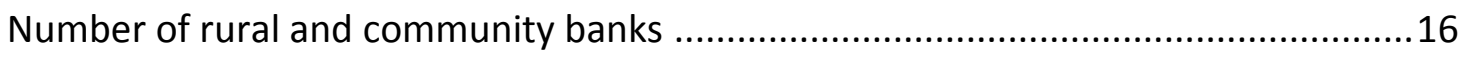

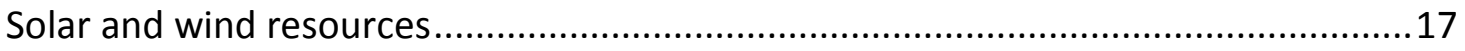

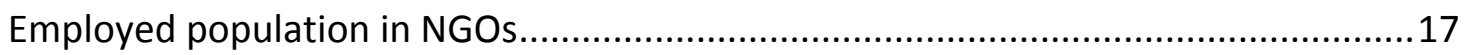

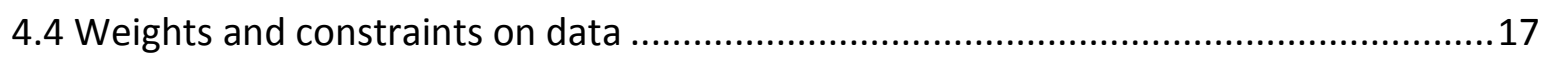

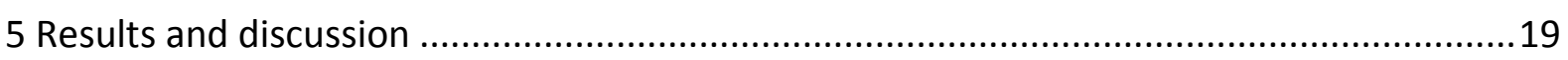

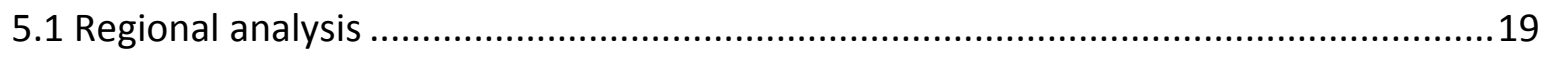

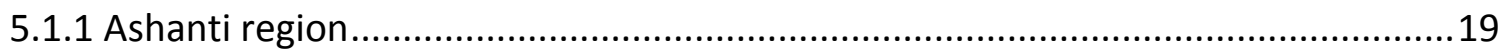

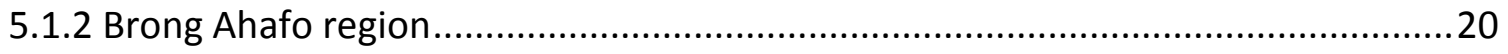

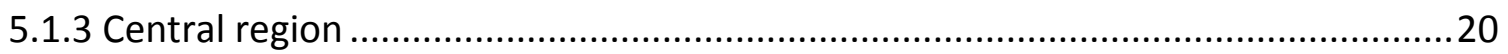

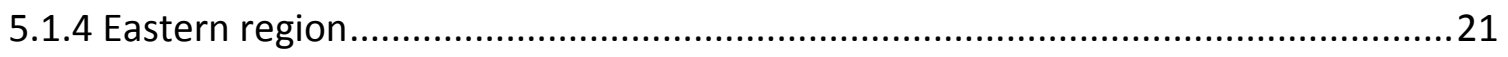

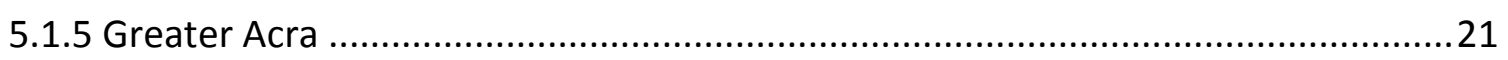

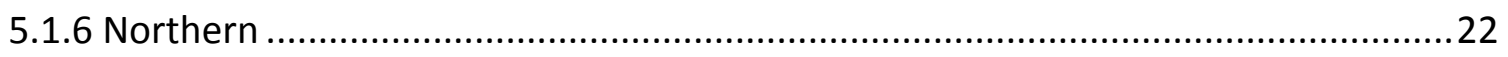

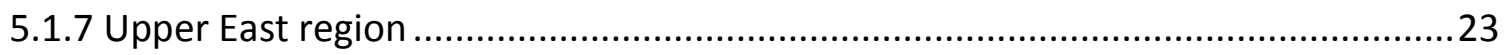

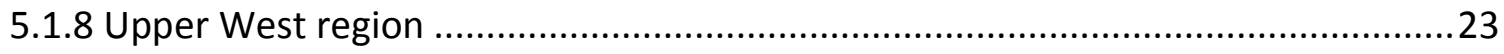

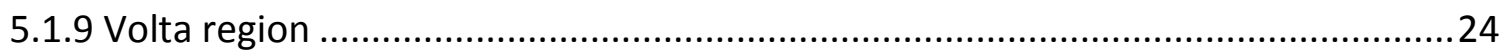




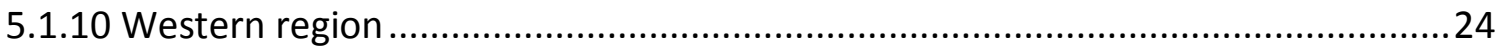

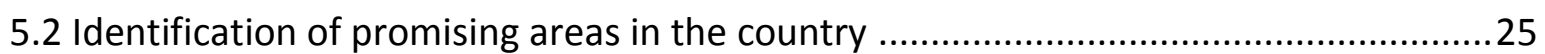

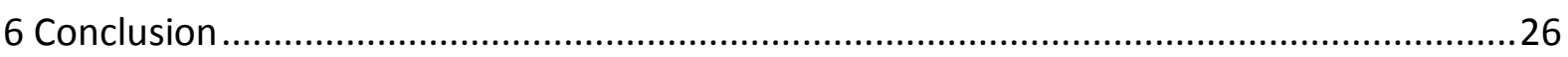

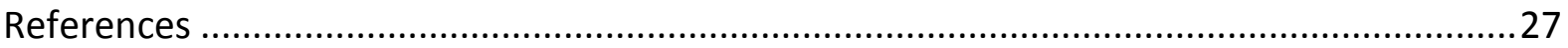




\subsection{Introduction}

According to the IEA, in 2013 17\% (1.2 billion people) of the global population lacked access to electricity and $38 \%$ (2.7 billion people) lacked clean cooking energy [1]. It is now well established that poor electricity access inhibits economic development by restraining economic activities and denying the population the opportunity to develop their human capital [2]. Furthermore, the critical role played by energy in achieving sustainable development has been well recognised in the energy policy literature [3]. Clean energy access is an important challenge for sustainability and economic growth, making rural electrification an important goal to be reached in developing countries. With the launch of Sustainable Energy for All initiative and the adoption of Sustainable Development Goals wherein Goal 7 specifically targets universal electrification by 2030, the importance of electricity access is now high on the policy agenda.

Energy access is predominantly a rural problem since $85 \%$ of those lacking electricity access live in rural areas [1]. High distances, difficulties of access, low number of consumers and low paying capacity of consumers are making rural electrification projects costly and risky for investors [2]. According to the Global Tracking Framework report in 2015, 222 million people gained access to electricity over the two year period between 2013 and 2015, which shows a marked improvement compared to the decadal average energy access rates of 84 million and 88 million between $1990-2000$ and 2000-2010 respectively. Yet, considering the backlog of electricity access at the moment and 1.5 billion an additional population 
expected between 2015 and 2030, the average access delivery rate has to reach 135 million per year [4]. This clearly shows the challenge ahead of us in meeting the universal energy access objective by 2030 .

A stakeholder analysis reported by IRENA [5] suggests that the identification of sites for mini-grid intervention is a time-consuming and resource-intensive process as it involves demand mapping, market development and community engagement. Availability of information and the upfront cost act as a barrier for private sector involvement in the sector. This is an area which has not received sufficient academic attention so far. While there are many studies on techno-economic analysis of technology selection and project viability analysis, they are site specific and do not necessarily help identify potential areas or sites for off-grid electricity investment particularly by the private sector. In a recent study, Pugazenthi et al. have looked into scaling-up and replication of mini-grid based electrification in several Indian states where they have considered the district as the unit of analysis [6]. However it does not propose a tool to analyse states or districts with best factors for a successful off-grid project. Yet, such a tool which enables identification of best areas at a local level would be interesting for governments, private investors and NGOs.

Accordingly, this paper follows the above idea presented in [6] and extends it with a supporting spreadsheet-based tool that can be used to undertake a preliminary assessment of potential areas that can be considered for off-grid electricity investment using local grids. The contribution of this paper resides in the development of a flexible tool that can be used to identify and compare potential areas for off-grid electrification. The tool is applied to a case study of Ghana to demonstrate its functionality and outcomes. Such a tool can offer 
the flexibility to the users of shortlisting and comparing potential areas using a systematic yet adaptable approach.

The paper is organised as follows: Section 2 presents a brief review of literature; section 3 presents the tool while the case study of Ghana is presented in section 4. Finally, concluding remarks are provided in the final section (section 5).

\subsection{Review of relevant literature}

Although the objective of universal electrification implies that the entire population will eventually have access to electricity, given the size of the challenge, a phased delivery approach is appropriate, which in turn makes appropriate site selection a crucial task. However, the motive for site selection is likely to be different for different stakeholders. A private investor may be interested in sites that offer better financially viability while donor agencies or governments may be interested in greater socio-economic impact by creating opportunities for transforming the lives of the population.

A study by GIZ [7] has considered the site selection parameters of solar mini-grids and suggested their ranking criteria. The report groups the parameters in five categories and under each group, a set of factors is considered (see Fig. 1). These factors are evaluated on a scale of 1 to 5 , with 1 representing weak and 5 representing strong. Stakeholder inputs are suggested for the evaluation process. The scores are then combined with equal weight, treating all of them equally important. A comparison of the overall scores for different sites provides a ranking of sites: sites receiving higher score are likely to generate higher impacts and could be prioritised for project implementation. While this approach is more adapted to 
local site selection once potential has been identified in a given area, it does not appear to be suitable for a more aggregated geographical level of analysis, for which detailed data is unlikely to be available in many cases and gathering such information will be costly for any investor.

Figure 1 here

A study on off-grid power supply in Kenya [8] produced for German investment Bank KfW used a four step process to identify sites for pilot projects. An initial list of 62 greenfield sites was compiled using previous studies by the government energy programmes, donor agencies such as GIZ and the Ministry of Energy. Ten best sites were shortlisted from this list using a set of criteria such as absence of national grid, sufficient demand for electricity, population density, economic activity, potential for solar-diesel hybrid systems, expansion potential and potential for synergies with other German-Kenyan projects. The shortlisted sites were then visited and data were collected to undertake another round of screening to identify three sites for pilot projects.

A few rural energy planning studies used the Network Planner package or similar tools. For example, Network Planner was used for Ghana in [9] and for Kenya in [10] to identify areas where grid extension, local mini-grids and stand alone solutions could be deployed. The tool combines the geographical information system with techno-economic assessment to offer a rich analytical outcome. However, it can deal with a limited set of technological options and requires extensive technical and geographical information, making it unsuitable for preliminary exploratory studies. GIS-based studies were also reported in [11] and [12] either at the regional level or country level but none of these studies focused on the identification of prioritised areas for electrification. 
Pugazenthi et al. [6] used a large number of districts within six Indian states and identified the most and least attractive areas within each state. The study considered the following indicators:

1. Levelised unit delivered cost of electricity (LUCEd)

2. Percentage of rural household electrification

3. Presence/absence of NGOs

4. Solar resource potential of the region

5. Biomass resource potential of the region

6. Presence of Akshay Urja shops (these are shops selling renewable energy products and are promoted by the Ministry of New and Renewable Energy).

7. Percentage of rural households availing bank accounts

Aggregation of these data required some normalisation since the indicators are measured in different units. The sum of normalised values has been calculated for each districts, giving a total average normalised value which ultimately enables classification of districts by ranks.

New Ventures India [13] reported a study of 13 Indian states to identify the markets for clean energy. Chosen indicators were rural un-electrification rate, access to bank finance, economic activity and the grid expansion over the last ten years in each state. By deleting states with less than $25 \%$ electrification rates and districts with low banking penetration and low economic growth, 116 districts among the 321 rural districts were considered. Ultimately by eliminating districts with more than $15 \%$ increase in electrification between 
2001 and 2011 the study proposed 80 districts as potential markets for rural electrification. A detailed study for the state of Uttar Pradesh using the same methodology is available in [14].

The literature has reported several other factors which have a direct influence for the realisation and the viability of a project. It is highlighted in [2] that the rate of success is directly dependant on the government's commitment in creating an enabling environment. For example the Electricity Act in India, the solar home systems program for off-grid areas in Bangladesh and the Rural Energy Development program in Nepal are giving robust institutional structures which can accompany project development. The need for appropriate institutions and human resources in the project area has also been reported in [2] since skills and means to manage the system on-site and collect revenue are essential on the long run.

There has been more success when intermediary organizations like electricity cooperatives or distribution franchises have helped the local planning process and have participated in decision making committees. Nonetheless community management system does not entice into maximizing profit and coverage of costs is more difficult [2]. Resources availability in the specific region and its variability during days and seasons are important qualitative parameters [15]. Stable quality and quantity of fuel/feed stock throughout the lifetime of the project must be available. The number of customers and their type are also important factors. Domestic rural customers include higher costs of generation because of lower plant load factor [2]. The presence of industrial customers enables lowering of costs, making the project more profitable. 
Finally, access to finance of the area is a very important factor for project viability since consumers have a low paying capacity. Financing mechanisms (micro-credits or consumer credit schemes, interest rate buy downs, fee for services mechanisms) available in the area will directly impact the financial viability of the project on the long run.

\subsection{The tool}

To facilitate high level of decision making for identification of markets for off-grid electrification, a worksheet based tool was developed ${ }^{1}$. It is designed to be a flexible tool that can be used in different contexts or geographical regions where the some pre-defined factors may not be appropriate. One of the objectives of the tool is to allow users to put data as required in a given context. Moreover, users may need to revise their options and choices based on the initial results. Thus, allowing them to copy and paste data and results remains important. To enable a user friendly tool three worksheets were defined: a sheet where the user can put his/her data, a sheet where calculations will be made and a Dashboard to launch calculations and see results (see Fig. 2).

Figure 2 here

The Dashboard plays a crucial role in the tool. The user can initialise the dataset, start the analysis and set weights for decision parameters or again specify the range (minimum or maximum values) for the data to be analysed. Results will also be shown on the Dashboard

\footnotetext{
${ }^{1}$ The tool, called SIPAI (Spreadsheet for Identification of Potential Areas for off-grid Intervention), is available from the corresponding author. It will be made available to the wider public in due course.
} 
and a graph enables to have a better view of results. The user can also specify the number of results to be reported. All analysis was done using Visual Basic, the Excel's programing language.

The initialization button enables the user to update the Dashboard sheet with names of criteria put by the user. Names are copied on the area of the sheet where results will be given, and on the area of the sheet which enables to put weights and constraints on criteria.

The analysis process starts by copying the data supplied by the user in the input sheet onto the calculus sheet. The original data remains unchanged this way. Each time an analysis is done, the data is copied onto the calculation sheet, so the user does not need to initialise the calculations again. The user can put constraints on maximum values or minimum values wanted for each criterion. Constraints are copied on the calculus sheet and compared with values of the given criteria. If an area does not fulfil the constraint, it is deleted from the calculus sheet and will not be taken into account at all.

Data in each column is then normalised ${ }^{2}$ but since the denominator cannot be equal to 0 , a constraint had to be put for the case where the maximum equals the minimum value. After normalisation the sum of normalised data is calculated for each area giving a total average of normalised values.

${ }^{2}$ the formula used is as follows: Value $=\frac{\mathrm{X}-\mathrm{Min}}{\mathrm{Max}-\mathrm{Min}}$ 
The numbers of results wanted by the user are then picked from the highest to the smallest. The corresponding area is identified and posted on the Dashboard with its data picked from the original data.

To ensure that the model is working correctly, an extensive trial was done and checks were carried out using different data sets. A small data set at the state level in India was first used to develop confidence in the model. The dataset used by [6] was then used to see if model reports the same result as reported there. In both the cases, the model performed excellently and produced results as expected.

\subsection{Identification of potential markets in Ghana}

\subsection{Introduction}

To assess the utility of the tool in identifying best areas for rural electrification projects, an identification of potential markets for off grid mini-grid projects in Ghana was carried out.

Off grid projects typically face high risks due to remote areas and poor population, making project profitability difficult. Another important point is the threat of the arrival of the grid in the project area, making off-grid installations obsolete. This case study expects to point out best areas where a potentially viable and successful mini grid project could be set up.

The choice of Ghana for the case study has been mainly motivated by the availability of enough data to make a relevant study, and the paucity of similar studies for the country. 
The purpose of the case study is to demonstrate the capabilities of the tool - not to make recommendations about Ghana's off-grid electrification options or investment choices.

\subsection{Methodology}

Ghana is administratively divided into ten regions, where each region covers a number of districts (see Fig. 3). The analysis first classifies the potential districts in each region. Then, to prove the robustness of the tool and to point best potential areas at a national level, all the districts will be assessed at the same time, that is 216 districts are analysed.

Figure 3 here

The tool requires the user to specify the factors to be considered for the analysis. Several criteria to assess the feasibility of a project proposed by [6] have been followed. The percentage of un-electrified rural households is very important. Rural banking access has also been reported as crucial to enable the financial viability of the project by enabling consumers to pay their bill [2]. Renewable energy resource potential is an important criterion for assessing the feasibility of decentralised energy interventions. As suggested by [13] and [14], the asset ownership such as mobile phone and internet access or computer ownership can also indicate how accessible a location is, which can be an important consideration for private investors. Accordingly, the following criteria are used for the identification of suitable locations for mini-grid based electrification in Ghana:

1. Rural Un-electrification

2. Rate of mobile phone owners

3. Rate of internet facility users 
4. Rate of desktop computers/ laptop owners

5. Number of rural and community banks

6. Solar resource potential of the district

7. Wind resource potential of the district

8. Employed population in NGOS

It is important to highlight here that the tool can deal with other factors as well. However, data availability limits the choice of a factor. For example, biomass is an important source of energy in rural Ghana but there is limited district level information about the availability of adequate biomass for electricity generation. Accordingly, this factor could not be included in the analysis.

\subsection{Data collection}

The study has relied on the Population and Housing Census of 2010 [16] that offers a large set of information. Clearly, more recent information would make the analysis better but in the absence of any other exhaustive source of information, the census data has been used.

\section{Rural un-electrification}

About $64 \%$ of the households in Ghana had access to electricity grids at the time of 2010 Census [16]. Rural electrification rates were available for almost each district of the country from the census data [16]. Rates available were divided in the census between three sources of electricity for households lighting (mains, private generator, solar) giving a total electrification rate by district. Un-electrification rates were then deduced. Unconnected communities would have been a better indicator as private investors are unlikely to invest in mini-grids for non-electrified households in a village where grid has reached. However, the 
information on unconnected communities is not available from the census or other data sources. Similarly, the island communities near Akosombo dam represent a concentration of non-electrified population that is difficult to connect through grid extension. Off-grid electrification initiatives are being taken by the government of Ghana in this area [17]. However, the census data does not distinguish these islands separately and accordingly, these areas could not be specifically considered in the analysis.

\section{Rate of mobile phone users/internet facility users/desktop computers or laptop} owners

The above three indicators available in census data were chosen to assess the wealth of districts. Economic strength implies an increase of consumption and buying power for consumers. The increase of consumption enables exploitation of scale economies which make price per kWh more affordable, making the project more financially viable in return.

\section{Number of rural and community banks}

As shown on table 1, the number of rural and community banks varies between 4 for Upper West to 25 for Ashanti. It represents a total of 137 institutions across the country for 216 districts. Many districts do not have even one rural bank. Since there were no data available about rural banking access, the number of rural bank by districts was chosen as the indicator. It is possible to include all banks in a district as the indicator, given that most of the banks may not be operating in the villages after all. One could also include other service providers such as post offices which offer limited banking facilities. More accurate data is required in this area to adequately capture the rural access to finance but at least we can presume that the more a district has rural banks, the more rural population should have access to financial services. 
Table 1 here

\section{Solar and wind resources}

Renewable resources are important for off grid projects since they insure autonomy and viability. Solar and wind resources data were obtained for each districts from [18].

\section{Employed population in NGOs}

Organisation strength is assessed by number of people employed in NGOS in districts [6] since there was no relevant information at a country level about NGOS by districts. It is assumed that the higher the number of people working in NGOs in a district indicates higher the district's organisational capability to manage decentralised mini-grid type of projects. The inherent assumption here is that the utility is unable to increase access to electricity in the district. There are self-help groups or such organisations which could provide vital local knowledge to private investors to support off-grid electrification.

\subsection{Weights and constraints on data}

The tool allows the user to specify weights to be assigned to each factor. The default is to treat all factors equally, with a weight of 1 . In the case study however a differential weighting rule has been used. This follows from the weighting principles followed in multicriteria decision making particularly in Analytical Hierarchy Process. Each factor is compared pairwise and one of the three values was used according to the following rules as suggested in [19]:

- 1 if a criterion is being compared with itself or if the criterion is equally important.

- $\quad 2$ if the criterion is placed in a slightly less important category (i.e. in the second tier). 
- 3 if the criterion is placed two categories below the best category (i.e. it is relatively less important than the others).

The weight coefficient is obtained by the division of the individual score of the criterion by the total score of all criteria (see table 2). Clearly, it is possible to use a scale of 5 or 7 but the user has to perform the weight calculations outside the tool. The desired weight for any given factor has to be entered into the worksheet.

\section{Table 2 here}

Rural banking access was put at a higher level because of the importance of financing for a successful project. In this way districts with rural banks will be privileged. Then, the criterion on NGOs presence was placed at a higher level above rural un-electrification rate in order to try to differentiate best districts more easily. The first three criteria belong to the same category and should have similar weights and importance in the decision process.

Energy resources were given equal importance, asset ownership was considered as less important while access to internet was given least importance because it is considered less relevant than the ownership of computers or mobile phones.

It must be highlighted here that the user has the flexibility of entering suitable weights based on an appropriate logical approach. The one indicated above relies on expert judgement but it is possible to decide them through stakeholder consultation or otherwise. Similarly, cost of service delivered could be considered as an important factor but due to data limitations, this was not considered here. Similarly, a constraint has been entered on electrification rates to ensure that the tool will not analyse districts with non-electrification rates less than $60 \%$. This is done to focus on areas with high non-electrification rate and to 
demonstrate the optional range that can be used in the tool. Analysis can be performed without entering these values.

\section{Results and discussion}

This section first presents the results of the regional level of analysis for 10 regions, followed by a consolidated analysis of best potential areas in the country.

\subsection{Regional analysis}

\subsubsection{Ashanti region}

The state Ashanti is composed of 30 districts. Among them, data were not available for 6 districts (Asante Akim North, Asokore Mampong Municipal, Bosome Freho, Kumawu, Mampong Municipal) reducing the number of districts to be analysed at 24 . Only 10 states satisfied the constraint on non-electrification rate, and only three of them have rural banks. Adansi South, Ejura/Sekyedumase, Atwima Mponua, Asante Akim south and Ahafo Ano south are the 5 most potential districts for setting up a mini grid project (see Fig. 4).

Figure 4 here

Table 3 here

Adansi South has one rural bank, a high number of population employed in NGOS and a high non-electrification rate (81.1\%). In the second position Ejura seems to have a particularly 
good profile for setting up a project with 2 rural banks, a high rate of non-electrification (71.7\%) and the best rates of laptop owners, mobile phone owners and internet users within the 10 states. Thereby this district presents a good potential market.

\subsubsection{Brong Ahafo region}

Brong Ahafo region is composed of 27 districts. Among them, data was not available or not enough available for 5 districts (Asutifi North, Dorma West, Nkoranza South, Nkoranza North and Techiman North), the remaining 22 districts were analysed. The constraint on rural non-electrifcation removed 7 other districts, leaving 15 districts fulfilling our criteria.

Top 5 (high potential) districts are Atebubu Amantin, Pru, Sunyani Municipal, Tain and Asufo North Municipal (see Fig. 5 and table 4). Pru earns a second place in the ranking due to the presence of a rural bank, a good NGOs presence and a high non-electrification rate. However, in terms of asset ownership, the district is very far below the mean of all 15 districts. Despite the second ranking, the financial viability of a project may be affected due to limited economic wealth of the district. Sunyani on the other hand has a good asset ownership and a high share of population in NGO activities. Accordingly, the district seems to possess economic and organisational strengths to set up successful mini grids projects.

Figure 5 here

Table 4 here

\subsubsection{Central region}


Among 20 districts of the region, one-half could not be analysed due to incomplete data and 7 other districts did not fulfil the restriction imposed on rural non-electrification rate, giving only three districts as suitable for analysis. All three districts present good potential for rural electrification projects (see Fig. 6 and table 5).

Figure 6 here

Table 5 here

\subsubsection{Eastern region}

Among the 25 districts of the eastern region 8 did not have enough data available, and out of the 17 remaining 12 districts had a high electrification rate, leaving ultimately 5 districts for analysis (see Fig. 7 and Table 6).

The region has obviously a well implanted rural electrification policy, which in turn increases the risks in setting up a mini grid project because it could be obsolete with the arrival of the grid in the area. So only Afram plain South and Afram Plains North are potential districts in the region. Both districts have high non-electrification rates (respectively 90.2 and $80.6 \%$ ) joint with good NGOs presence and a rural bank for Afram Plains South. Economic indicators are better for Afram plains North but the lack of rural bank and the higher electrification rate confirm the place of Afram Plain South as a better position for a mini grid project.

Figure 7 here

Table 6 here

\subsubsection{Greater Acra}


Among the 16 districts of the region 4 could not be analysed due to data limitations. The region has a very good electrification rate, making a mini grid project very unlikely to be successful in the region.

\subsubsection{Northern}

In the Northern region 3 districts were not available for analysis, while among the 23 remaining districts 21 had rural non-electrification rate over $60 \%$. According to the classification (see Fig. 8 and table 7) Gushiegu is the best district to set up a project. The district has a high non-electrification rate $(92.9 \%)$ associated with the availability of a rural bank and a high number of population employed in NGOs (252) as compared to other districts.

West Manprusi presents a good non-electrification rate (82.5\%), a rural bank and a good presence of NGOS too. Furthermore we can notice that the internet user rate and the mobile phone owners rate are both over the mean of the districts. It seems to be more relevant to compare the rate of computers owners $(1.4 \%)$ with the median value which is at 0.9. In this way we can make the hypothesis that economic factors are available for a successful project in the district.

Figure 8 here

Good economic indicators can also be observed for Savelugu (ranked 3), Tolon (ranked 4) and West Gonja (ranked 5). However Savelugu and Tolon also have lower non-electrification rates (64.3 and 65.4) which may imply more risks. Top 7 districts all have at least one rural bank which increases their potential for successful projects. 
Table 7 here

\subsubsection{Upper East region}

For the 13 districts of the Upper East region, 1 has no data available and one did not fulfil the condition imposed on electrification, leaving 12 districts for analysis. Top ranking districts are Bongo, Garu Tempane, Bawku West and Builsa North (see Fig. 9 and table 8). They all have a rural bank and high non-electrification rates ranging between 91.4 (GaruTempane) and $83.7 \%$ (Builsa North). The number of population employed in NGOs is low at Builsa as compared to the mean of districts (138). Economic indicators are not particularly good for these districts. In particular Garu Tempane (ranked 2) and Bawku West (ranked 3) have low economic indicator values. Despite that, once again the availability of rural banks makes them good candidates for a mini grid project.

Figure 9 here

Table 8 here

\subsubsection{Upper West region}

In the region data was not available for one district and 3 others did not fulfil the $60 \%$ nonelectrification rate, leaving 8 districts as potential candidates (see Fig. 10). Jirapa, Wa East and Sissala East are the three first districts with $90.7 \%, 90.1 \%$ and $76 \%$ of rural nonelectrification rate respectively (see table 9). Only Jirapa (ranked 1) and Sissala Esat (ranked 3) have rural banks and they also have better economic indicators as compared to Wa East (ranked 2). Wa East has a better rural non-electrification rate than Sissala East, representing 
a higher market. It explains the second rank of the district in the classification but a mini project in Jirapa and Sissala could probably be more profitable.

Figure 10 here

Table 9 here

\subsubsection{Volta region}

The region has 25 districts, but data was not complete for 2 of them and 10 did not fulfil the non-electrification condition, leaving 13 districts for analysis (see Fig. 11). Akatsi South, Ketu South, South Tongu and Nkwanta South are the four first districts (see table 10). They all have a rural bank except for Ketu South which is ranked second. For this district the high number of people employed in NGOs (213) should reflect a good NGOs presence which may compensate this lack of rural banks. Districts with rural bank are always advisable and so Akatsi South, South Tongu and Nkwanta South are suggested to be analysed before Ketu South by project holders.

Figure 11 here

Table 10 here

\subsubsection{Western region}

The Western region has 22 districts but data was not available for two of them and 8 others were excluded as they have high electrification rates, leaving 12 districts for analysis (see 
Fig. 12). Top four districts are Bia West, Amenfi Central, Wassa Eat and Amenfi West (see Table 11).

Figure 12 here

Bia West (ranked 1) and Wassa East (ranked 2) seem to be good candidates, both have got a rural bank and non-electrification rates are satisfying. Some precautions should be taken with Amenfi (ranked 2) whose rural non-electrification rate is near $60 \%$ and whose two economic indicators were not available. Other investigations could be advisable for this district. Amenfi West presents good characteristics too but unfortunately the district does not have a rural bank, making it less interesting than Bia West, Amenfi Central and Wassa East.

Table 11 here

\subsection{Identification of promising areas in the country}

We now turn to identify the best region where work should be concentrated for the identification of a project area. All the districts are analysed together but excluding districts with data incompleteness, there are actually 179 districts to be analysed, representing about 1432 data points.

Once again, we put $60 \%$ as minimum value for the non-electrification rate of a district. It gives us 95 remaining districts out of 179 . We chose to retain the 45 best districts which represent about the quarter of the total number of districts. 
Table 12 presents the list of 45 promising districts ranked by their average score. Gushiegu district in the Northern region tops the table, followed by Upper Denkyira in the Central region. High rates of non-electrification supported by high levels of NGO activity make them attractive. Among them 10 districts are in the Northern region, 9 in Volta and 7 in Upper East; representing more than one-half of the selected districts (see table 13).

Northern, Volta and Upper East are thereby good candidates for an off-grid project and an analysis for rural electrification should begin in one of these three regions. On the other side with only two districts in the classification, the Western region offers a very limited potential. Greater Acra and Upper West are not present in the classification and thereby these regions should be avoided.

Table 12 here

Table 13 here

\section{Conclusion}

The Excel tool enabled us to analyse the district level data in a systematic way to prepare a ranking of potential districts using a set of criteria. The tool allows the user to decide the factors relevant for a given study and provide a preliminary shortlisting of areas for off-grid intervention. As the factors can be changed or constraints can be varied, it facilitates modification and refining of the analysis. The tool can be used at different levels: at an 
aggregate level, it is possible to apply the tool at the global level or national level. As long the users can identify the potential criteria for analysis and enter the data accordingly, it can provide a ranking. At the national level, the tool can be used to identify potential provinces where an intervention is preferred or at a more disaggregated level to identify the districts or even villages within a district.

Clearly, the advantage of the tool is its ability to deal with large data and its flexibility to deal with user-defined factors, as long as limited set of requirements are observed. However, our case study has shown that data availability can be an issue, more so at the disaggregated level. This is an area that requires greater attention. Where data is available or suitable proxies can be made, the tool offers a convenient way of supporting the off-grid intervention analysis.

\section{References}

[1] International Energy Agency, "World Energy Outlook 2015," International Energy Agency, Paris, 2015.

[2] S. Bhattacharyya, Rural Electrification through Decentralised Off-grid Systems in Developing Countries, London: Springer-Verlag, 2013.

[3] S. Bhattacharyya, "Energy access programmes and sustainable development: A critical review and analysis," Energy for Sustainable Development, vol. 16, no. 3, pp. 260-71, 2012.

[4] "Progress towards sustainable energy, Global Tracking Framework 2015, Summary Report," ESMAP, WOrld Bank and IEA, New York, 2015. 
[5] "Accelerating off-grid renewable energy, IOREC 2014, Key Findings and Recommendations," International Renewable Energy Agency, Abu Dhabi, 2015.

[6] D. Pugazenthi, G. Sarangi, A. Mishra and S. Bhattacharyya, "Replication and scaling-up of isolated mini-grid type of off-grid interventions in India," AIMS Energy, vol. 4, no. 2, pp. 222-255, 2016.

[7] "Where shall we put it? Solar mini-grid site selection handbook," GIZ ProSolar, Nairobi, 2014.

[8] ECA, TTA and Access Energy, "Kenya Off-grid Power Supply, Final Report," Economic Consulting Associates, London, 2014.

[9] F. Kemausuor, E. Adkins, I. Adu-Poku, A. Brew-Hammond and V. Modi, "Electrification Planning using Network Planner Tool: The case of Ghana," Energy for Sustainable Development, vol. 19, no. April, pp. 92-101, 2014.

[10] L. Parshall, D. Pillai, S. Mohan, A. Sanoh and V. Modi, "National electricity planning in settings with low pre-existing grid coverage: development of a spatial model and case study of Kenya," Energy Policy, vol. 37, pp. 2395-2410, 2009.

[11] S. Szabo, K. Bodis, T. Huld and M. Moner-Girona, "Energy solutions in rural Africa: mapping electrification costs of distributed solar and diesel generation versus grid extension," Environmental Research Letters, vol. 6, no. 3, 2011.

[12] D. Mentis, M. Welsch, F. B. O. Nerini, Howells, M, M. Bazilian and H. Rogner, "A GISbased approach for electrification planning-A case study on Nigeria," Energy for Sustainable Development, vol. 29, pp. 142-150, 2015.

[13] "Identifying Micro-Markets For Clean Energy Access," New Ventures India, Hyderabad, India, undated.

[14] S. Sanyal and P. a. B. S. Deka, "Identifying micro-markets for clean energy access in Uttar Pradesh: An analysis of unelectrification, banking services and asset ownership data in Uttar Pradesh," New Ventures India, Hyderabad, 2014.

[15] S. Bhattacharyya and D. Palit, Mini-grids for Rural Electrification of Developing Countries, London: Spinger-Verlag, 2014.

[16] "2010 Population and Housing Census - Summary report of final results," Ghana Statistical Service, Accra, 2012.

[17] Ministry of Energy, Ghana, "Scaling-up Renewable Energy Program in Ghana Investment Plan," Ministry of Energy, Ghana, Accra, 2015.

[18] UNEP, "Solar and Wind Energy Resource Assessment (SWERA)," United Nations Environment Programme, undated. 
[19] D. Jagu, D. Pugazenthi and V. Kishore, “Application of Multi-criteria Decision Aids for Selection of Off-Grid Renewable Energy Technology Solutions for Decentralised Electrification," in Mini-grids for Rural Electrification of Developing Countries, London, Springer, 2014, pp. 283-311.

[20] "Bank of Ghana. Register of Rural and Community Banks as of January 2013," Bank of Ghana, Accra, 2013.

[21] S. Kohli, P. Raman and V. Kishore, "Evaluation of various fuels, for gasification," in Energy options for the 90's: proceedings of the National Solar Energy Convention held at Indian Institute of Technology, Delhi, December 2-4, 1987, New Delhi, Tata McGraw Hill, Solar Energy Society of India., 1988, pp. 50-14. 
List of figures

Fig. 1: Parameters for mini-grid site selection

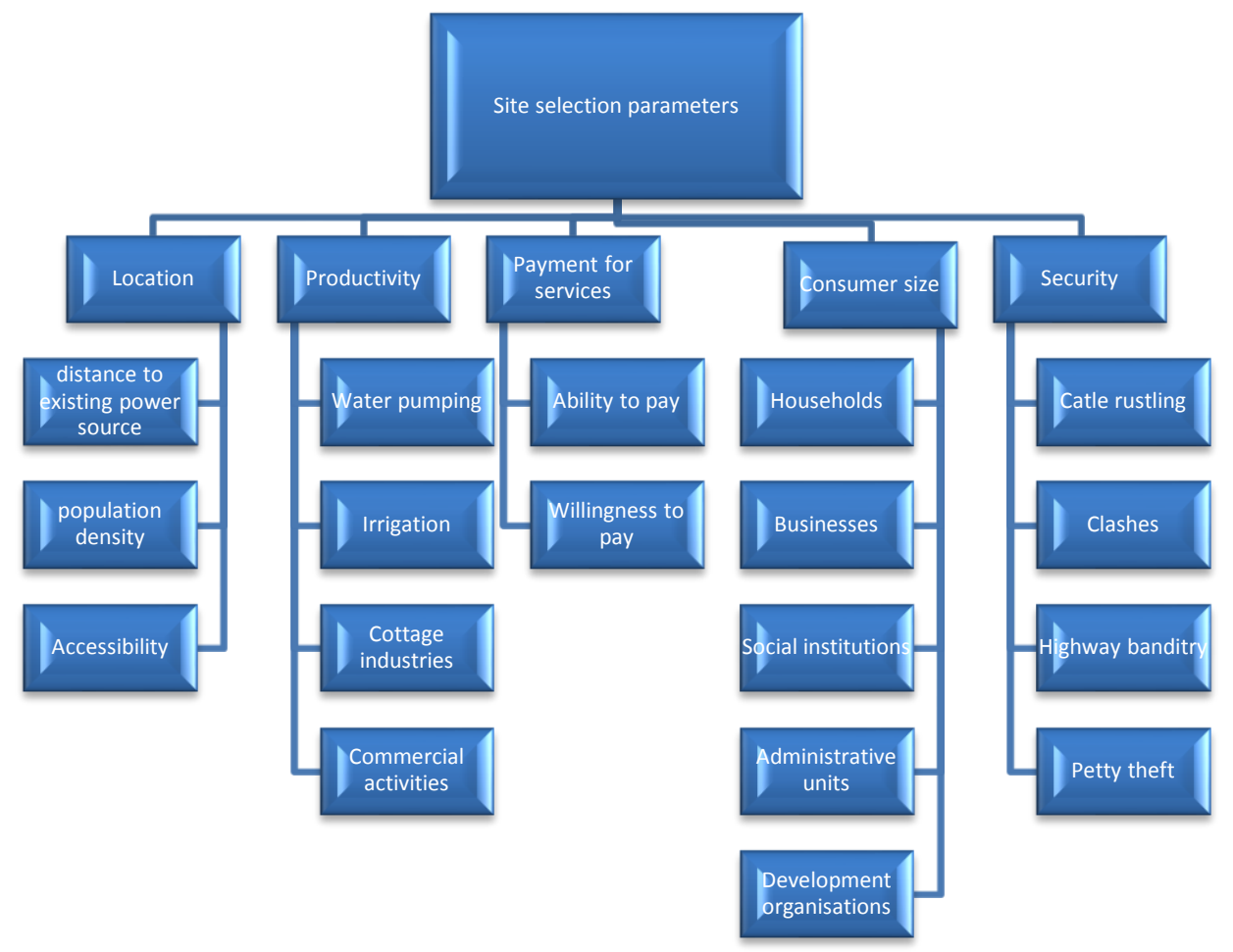

Source: [7] 
Fig. 2: Worksheet structure

\section{Input data}

\begin{tabular}{|c|c|c|c|c|c|c|c|c|}
\hline assam & $\begin{array}{l}\text { Name of the } \\
\text { district }\end{array}$ & \begin{tabular}{|l|} 
Cost of \\
electricity \\
delivered to the \\
grid
\end{tabular} & $\begin{array}{l}\text { Un- } \\
\text { electrification } \\
\text { rate }\end{array}$ & $\begin{array}{l}\text { Total No. of } \\
\text { NGOs }\end{array}$ & $\begin{array}{l}\text { Total solar } \\
\text { power potential } \\
\text { available }\end{array}$ & \begin{tabular}{|l|} 
Total biomass \\
power potential \\
available
\end{tabular} & \begin{tabular}{|l} 
Rural HHs \\
availing \\
banking \\
services \\
\end{tabular} & $\begin{array}{l}\text { Total No. of } \\
\text { Akshay Urja } \\
\text { shops }\end{array}$ \\
\hline assam & Baksa & 2.47 & 72.27 & $\circ$ & $448 \circ 8$ & $\circ$ & 33.27 & $\circ$ \\
\hline assam & Barpeta & 2.47 & 80.61 & 7 & 91850 & 20.03 & 33.39 & o \\
\hline assam & Bongaigaon & 2.47 & 76.5 & 1 & 133034 & 12.98 & 54.25 & o \\
\hline assam & Cachar & 2.56 & 71.45 & 6 & 21432 & 41.3 & 35.05 & o \\
\hline assam & Chirang & 2.47 & 80.53 & o & 23019 & $\circ$ & 34.76 & $\circ$ \\
\hline assam & Darrang & 2.47 & 79.92 & 2 & 146366 & 18.22 & 34.53 & o \\
\hline assam & Dhemaji & 2.47 & 82.93 & 2 & 157430 & 8.2 & 32.73 & o \\
\hline assam & Dhubri & 2.47 & 88.45 & 이 & 30780 & 16.21 & 19.34 & o \\
\hline
\end{tabular}

\section{Calculus}

\begin{tabular}{|c|c|c|c|c|c|c|c|c|}
\hline Max: & 2.56 & 88.45 & 38 & $5 E+06$ & 144.8 & 69.66 & 1 & \\
\hline Min: & 2.47 & 47.46 & 0 & 2355 & 0 & 19.34 & 0 & \\
\hline Name & $\begin{array}{l}\text { Cost of } \\
\text { electricit } \\
y \\
\text { delivere } \\
d \text { to the } \\
\text { grid }\end{array}$ & $\begin{array}{l}\text { Un- } \\
\text { electrific } \\
\text { ation } \\
\text { rate }\end{array}$ & $\begin{array}{l}\text { Total } \\
\text { No. of } \\
\text { NGOs }\end{array}$ & $\begin{array}{l}\text { Total } \\
\text { solar } \\
\text { power } \\
\text { potential } \\
\text { availabl } \\
\text { e }\end{array}$ & $\begin{array}{l}\text { Total } \\
\text { biomass } \\
\text { power } \\
\text { potential } \\
\text { availabl } \\
\text { e }\end{array}$ & $\begin{array}{l}\text { Rural } \\
\mathrm{HHs} \\
\text { availing } \\
\text { banking } \\
\text { services }\end{array}$ & $\begin{array}{l}\text { Total No. of Akshay Uria } \\
\text { shops }\end{array}$ & Total average values \\
\hline Baksa & 0 & 0.6053 & 0 & 0.0093 & 0 & 0.2768 & 0 & 0.891442258 \\
\hline Barpeta & 0 & 0.8087 & 0.1842 & 0.0197 & 0.1383 & 0.2792 & 0 & 1.430184982 \\
\hline Bongaigaon & 0 & 0.7085 & 0.0263 & 0.0288 & 0.0896 & 0.6938 & 0 & 1.546946002 \\
\hline Cachar & 1 & 0.5853 & 0.1579 & 0.0042 & 0.2852 & 0.3122 & 0 & 2.344781399 \\
\hline Chirang & 0 & 0.8068 & 0 & 0.0045 & 0 & 0.3064 & 0 & 1.117769312 \\
\hline Darrang & 0 & 0.7919 & 0.0526 & 0.0317 & 0.1258 & 0.3019 & 0 & 1.303927252 \\
\hline Dhemaji & 0 & 0.8653 & 0.0526 & 0.0341 & 0.0566 & 0.2661 & 0 & 1.274825146 \\
\hline
\end{tabular}

\section{Results dashboard}

\section{Results}

1) Put your data on the "Put data here" sheet

2) Click on "INIT"

3) Enter weights in the table

4) Click on "Analysis"

Y You must click on "IIJIT" each time you change column names on the "Put data here" sheet

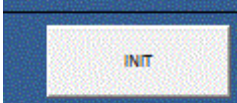

Shov "Put data here- first's column in

Number of results yanted (mas 100, min 100

Choose your weights and constraints:

Variable

Un-electrific ation rate

\begin{tabular}{l} 
Un-electrification rate \\
\hline Total No. of NGOs \\
\hline
\end{tabular}

Total solar power potential arabe

Total biomass power potential available

Rural HHs availing banking services

Total No. of Akshay Uria shops
ANALYSIS (1)

Weights MIN TMAX

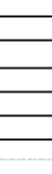

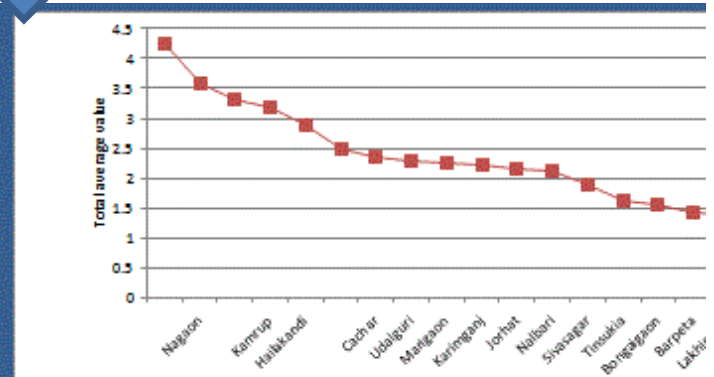


Fig. 3: Map of Ghana with its regions




Fig. 4: Ranking of districts in Ashanti region

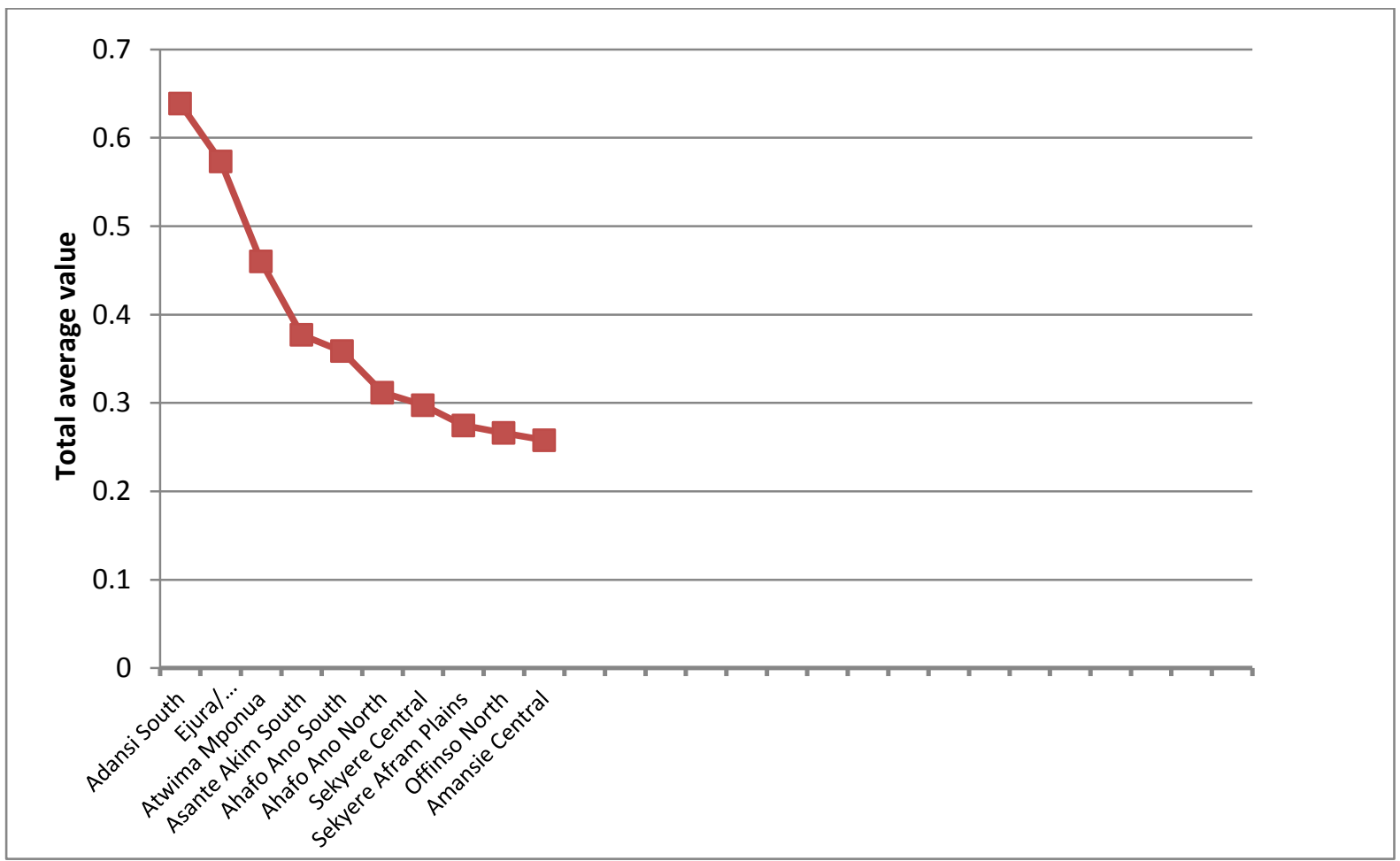


Fig. 5: Potential areas in Brong Ahafo region

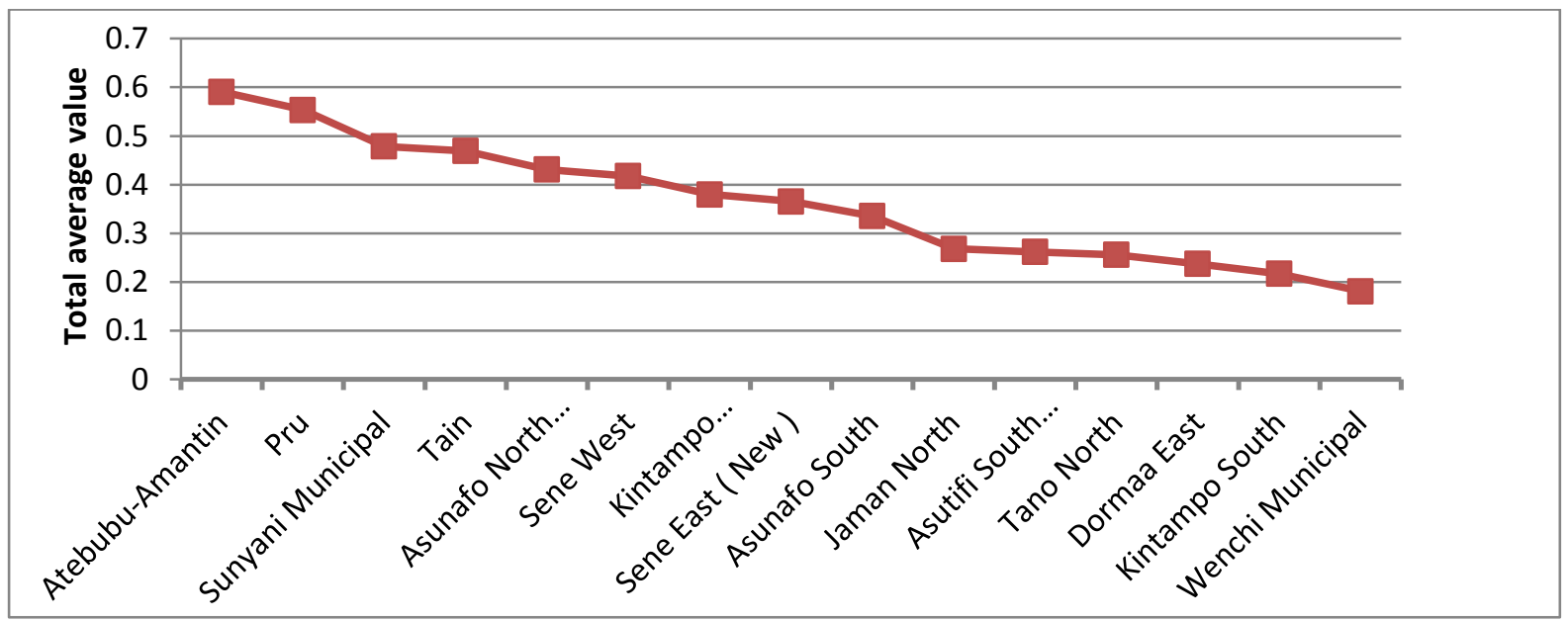


Fig. 6: Potential areas of central region

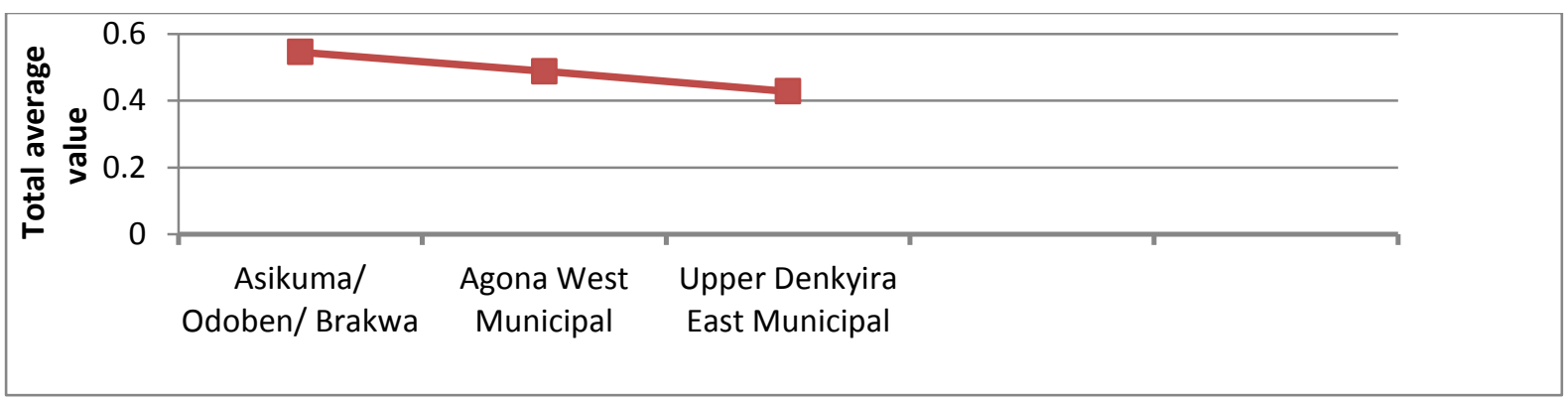


Fig. 7: Potential areas in the Eastern region

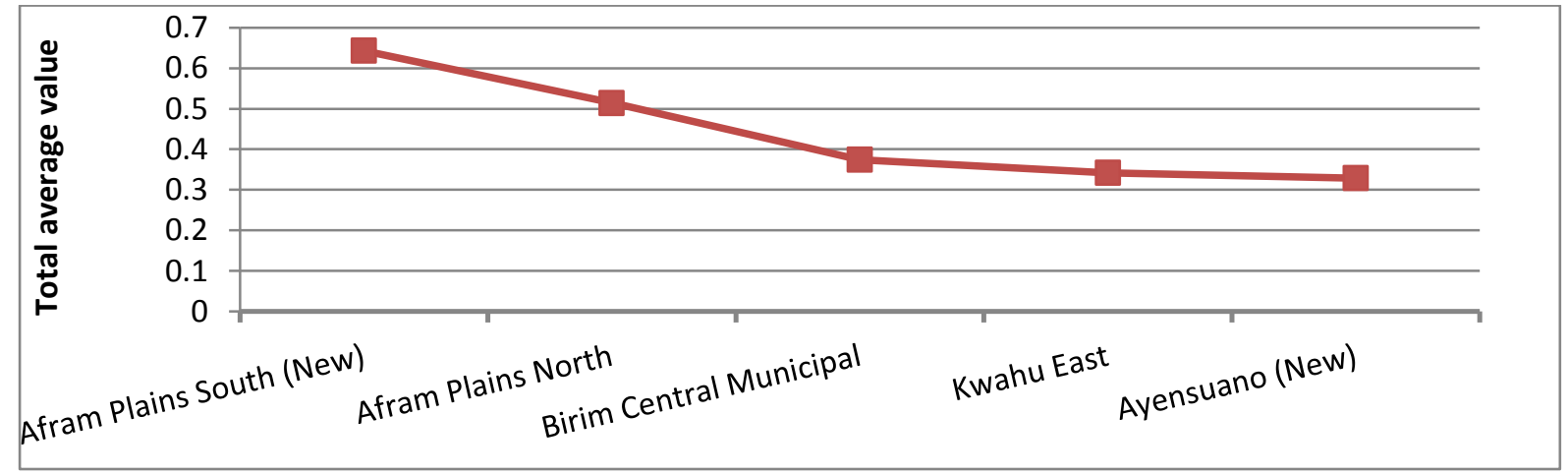


Fig. 8: Potential areas in the Northern region

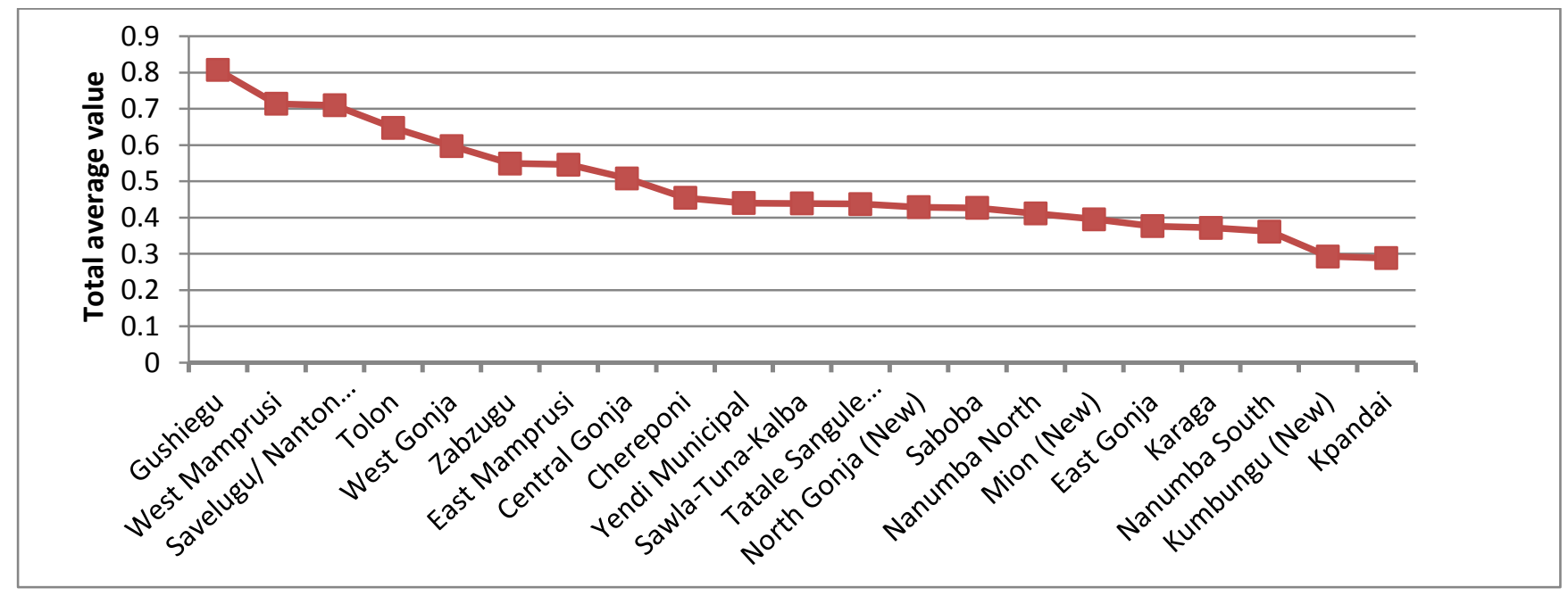


Fig. 9: Potential districts in Upper East Region

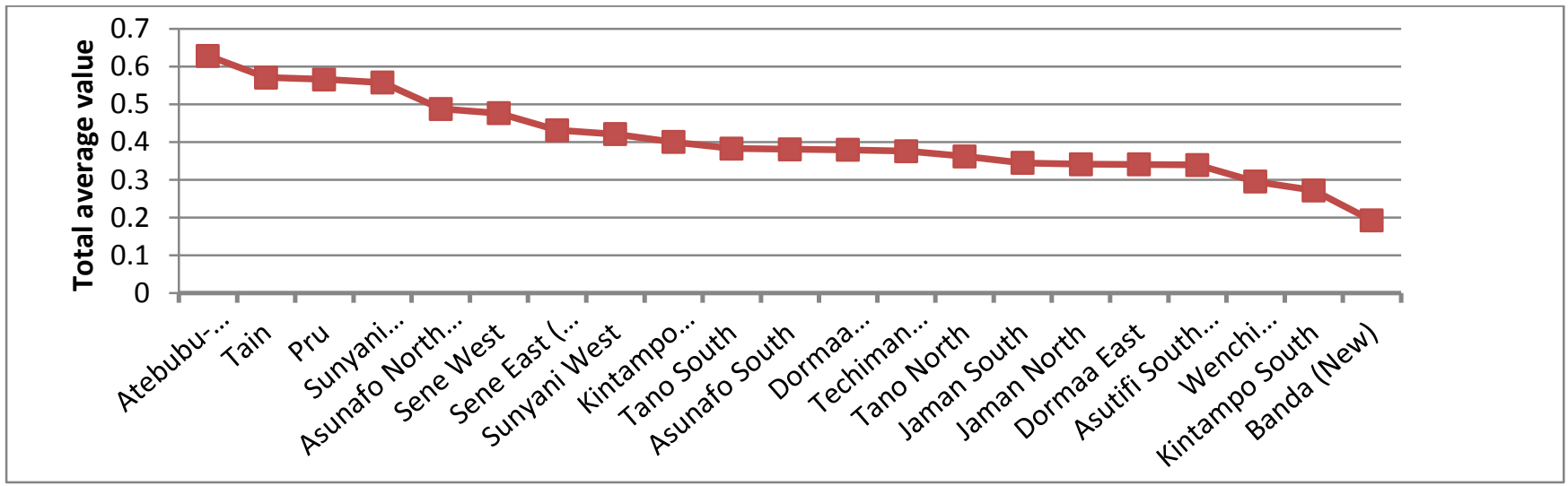


Fig. 10: Potential areas in the Upper West region

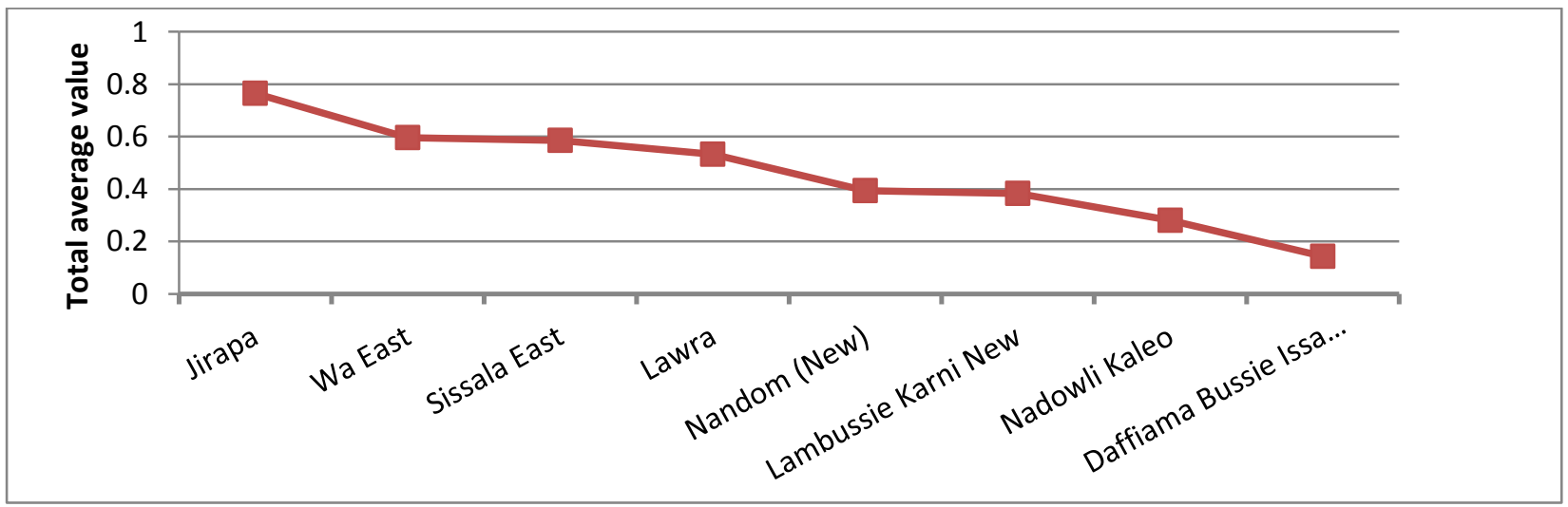


Fig. 11: Potential areas in the Volta region

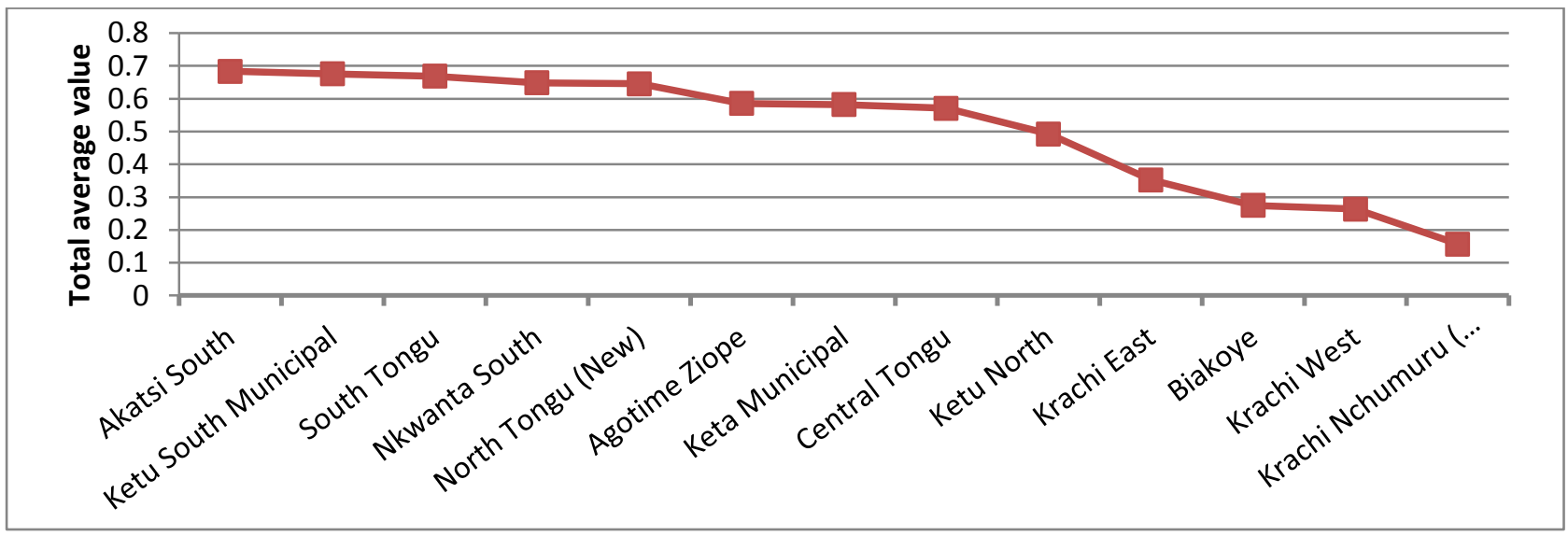


Fig. 12: Potential areas in the Western region

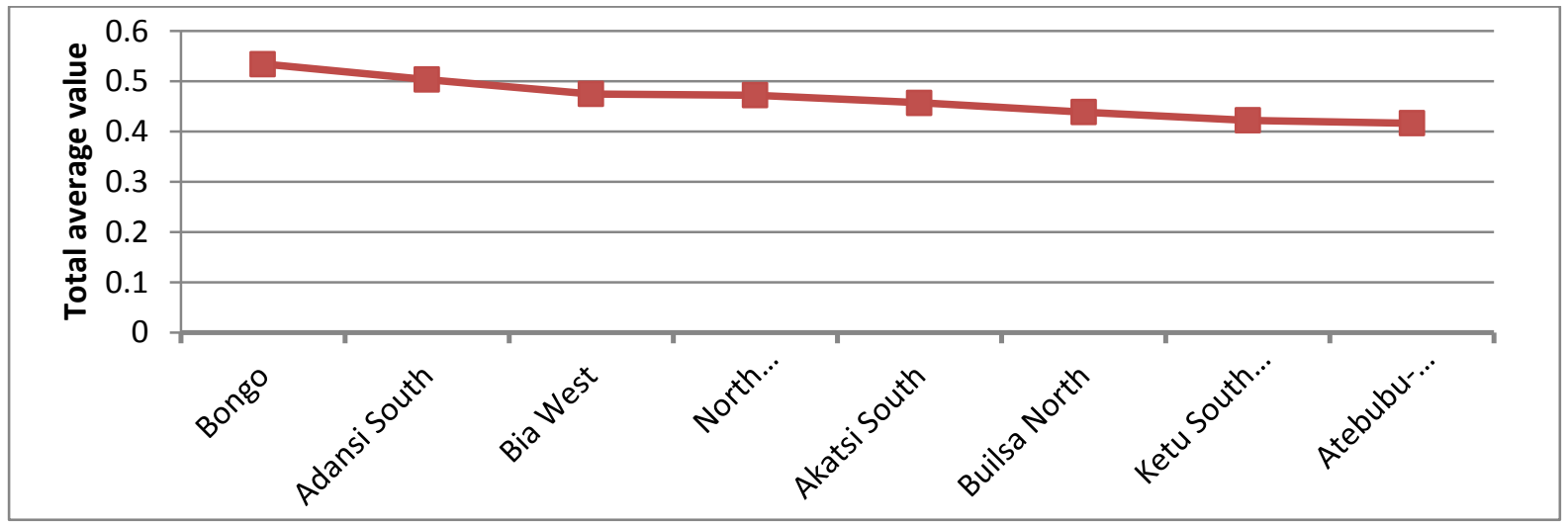


List of tables

Table 1: Register of Rural and Community Banks as of January 2013

\begin{tabular}{llc}
\hline & REGION & NUMBER \\
\hline 1. & ASHANTI & 25 \\
2. & CENTRAL & 21 \\
3. & EASTERN & 22 \\
4. & BRONG AHAFO & 20 \\
5. & WESTERN & 14 \\
6. & VOLTA & 12 \\
7. & GREATER ACCRA & 7 \\
8. & UPPER EAST & 5 \\
9. & UPPER WEST & 4 \\
10. & NORTHERN & 7 \\
\hline
\end{tabular}

Source: [20] 
Table 2: Calculation of weights

\begin{tabular}{|c|c|c|c|c|c|c|c|c|c|c|c|}
\hline & Criteria & 1 & 2 & 3 & 4 & 5 & 6 & 7 & 8 Total & \multicolumn{2}{|c|}{ Weights } \\
\hline 1. & Banking & 1 & 1 & 1 & 2 & 2 & 3 & 3 & 3 & 16 & 0.24 \\
\hline 2. & NGOs & & 1 & 1 & 2 & 2 & 3 & 3 & 3 & 15 & 0.23 \\
\hline 3. & rural un-electrification & & & 1 & 2 & 2 & 3 & 3 & 3 & 14 & 0.21 \\
\hline & Solar & & & & 1 & 1 & 2 & 2 & 2 & 8 & 0.12 \\
\hline & Wind & & & & & 1 & 2 & 2 & 2 & 7 & 0.11 \\
\hline & $\begin{array}{l}\text { Computer ownership } \\
\text { Mobile phone }\end{array}$ & & & & & & 1 & 1 & 1 & 3 & 0.04 \\
\hline & ownership & & & & & & & 1 & 1 & 2 & 0.03 \\
\hline 8. & Internet access & & & & & & & & 1 & 1 & 0.01 \\
\hline Total & & & & & & & & & & 66 & \\
\hline
\end{tabular}


Table 3: Best potential districts in Ashanti region

\begin{tabular}{|c|c|c|c|c|c|c|c|c|c|c|}
\hline 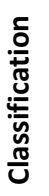 & Districts & $\begin{array}{l}\text { Rural } \\
\text { banks }\end{array}$ & $\begin{array}{l}\text { Employed } \\
\text { population } \\
\text { in NGOs }\end{array}$ & $\begin{array}{l}\text { Rural non- } \\
\text { electrification } \\
\text { rate } \\
\text { (\%) }\end{array}$ & $\begin{array}{c}\text { Annual } \\
\text { average } \\
\text { radiation }\end{array}$ & $\begin{array}{l}\text { Annual } \\
\text { averag } \\
\text { e wind } \\
\text { speed }\end{array}$ & $\begin{array}{l}\text { Desktop/lapto } \\
\text { p computers } \\
\text { owners } \\
\text { (\%) }\end{array}$ & $\begin{array}{c}\text { Mobile } \\
\text { phones } \\
\text { owners } \\
(\%)\end{array}$ & $\begin{array}{c}\text { Interne } \\
t \\
\text { facility } \\
\text { users } \\
(\%)\end{array}$ & $\begin{array}{c}\text { Total } \\
\text { average of } \\
\text { normalised } \\
\text { values }\end{array}$ \\
\hline 1. & Adansi South & 1 & 119 & 81.1 & 4.69 & 3.48 & 1.3 & 29 & 1.4 & 0.639657 \\
\hline 2. & $\begin{array}{l}\text { Ejura/ } \\
\text { Sekyedumase } \\
\text { Municipal }\end{array}$ & 2 & 86 & 71.7 & 4.64 & 2.85 & 3.1 & 39.2 & 3 & 0.587482 \\
\hline 3. & $\begin{array}{l}\text { Atwima } \\
\text { Mponua }\end{array}$ & 1 & 156 & 80.3 & 4.3 & 2.88 & 1.1 & 30.9 & 1.1 & 0.461835 \\
\hline 4. & $\begin{array}{l}\text { Asante Akim } \\
\text { South }\end{array}$ & & 188 & 60.7 & 4.46 & 3.07 & 2.6 & 36.2 & 2.1 & 0.381027 \\
\hline 5. & $\begin{array}{l}\text { Ahafo Ano } \\
\text { South }\end{array}$ & & 191 & 72.7 & 4.34 & 2.88 & 1.5 & 29.9 & 1 & 0.358773 \\
\hline 6. & $\begin{array}{l}\text { Ahafo Ano } \\
\text { North }\end{array}$ & & 113 & 75.4 & 4.43 & 2.88 & 2.6 & 33 & 1 & 0.316097 \\
\hline 7. & $\begin{array}{l}\text { Sekyere } \\
\text { Central }\end{array}$ & & 82 & 81.5 & 4.36 & 3.07 & 1.7 & 28.1 & 1 & 0.299396 \\
\hline 8. & $\begin{array}{l}\text { Sekyere Afram } \\
\text { Plains }\end{array}$ & & 33 & 93 & 4.51 & 2.85 & 0.6 & 14.6 & 1 & 0.277389 \\
\hline 9. & Offinso North & & 78 & 75 & 4.51 & 2.85 & 1.9 & 32.8 & 1 & 0.269965 \\
\hline $\begin{array}{l}1 \\
0\end{array}$ & $\begin{array}{l}\text { Amansie } \\
\text { Central }\end{array}$ & & 76 & 65.5 & 4.58 & 3.07 & 1.9 & 28.7 & 1.3 & 0.260714 \\
\hline & Mean & - & 112.2 & 75.69 & 4.482 & 2.988 & 1.83 & 30.24 & 1.39 & 112.2 \\
\hline & Median & - & 113 & 75.4 & 4.46 & 2.88 & 1.7 & 30.9 & 1 & 113 \\
\hline & $\begin{array}{l}\text { Standard } \\
\text { deviation }\end{array}$ & - & 51.9 & 9.05 & 0.12 & 0.19 & 0.76 & 6.52 & 0.66 & 51.9 \\
\hline
\end{tabular}


Table 4: Best potential districts of Brong Ahafo region

\begin{tabular}{|c|c|c|c|c|c|c|c|c|c|c|}
\hline 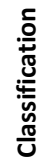 & District & $\begin{array}{l}\text { Rural } \\
\text { banks }\end{array}$ & $\begin{array}{l}\text { Employed } \\
\text { population in } \\
\text { NGOs }\end{array}$ & $\begin{array}{l}\text { Rural non- } \\
\text { electrification } \\
\text { rate } \\
(\%)\end{array}$ & $\begin{array}{c}\text { Annual } \\
\text { average } \\
\text { radiation }\end{array}$ & $\begin{array}{c}\text { Annual } \\
\text { average } \\
\text { wind } \\
\text { speed }\end{array}$ & $\begin{array}{l}\text { Desktop/laptop } \\
\text { computers } \\
\text { owners } \\
(\%)\end{array}$ & $\begin{array}{c}\text { Mobile } \\
\text { phones } \\
\text { owners } \\
(\%)\end{array}$ & $\begin{array}{c}\text { Internet } \\
\text { facility } \\
\text { users } \\
(\%)\end{array}$ & $\begin{array}{c}\text { Total average } \\
\text { of } \\
\text { normalised } \\
\text { values }\end{array}$ \\
\hline 1. & Atebubu-Amantin & 1 & 104 & 78.1 & 4.76 & 2.92 & 2.8 & 29.5 & 2 & 0.590646 \\
\hline 2. & Pru & 1 & 132 & 84.7 & 4.7 & 2.8 & 0.8 & 20 & 0.5 & 0.553391 \\
\hline 3. & Sunyani Municipal & 1 & 157 & 68.5 & 4.31 & 2.79 & 16.7 & 66 & 20 & 0.478568 \\
\hline 4. & Tain & 2 & 120 & 62.6 & 4.42 & 2.81 & 2.4 & 35.1 & 1 & 0.469305 \\
\hline 5. & $\begin{array}{l}\text { Asunafo North } \\
\text { Municipal }\end{array}$ & & 163 & 73.2 & 4.44 & 2.88 & 3.5 & 40.8 & 3 & 0.430979 \\
\hline 6. & Sene West & & 93 & 71 & 4.89 & 2.92 & 1.2 & 18.8 & 1 & 0.417672 \\
\hline 7. & $\begin{array}{l}\text { Kintampo } \\
\text { Municipal }\end{array}$ & 1 & NA & 92.7 & 4.38 & 2.8 & 3.4 & 33.9 & 2.5 & 0.380044 \\
\hline 8. & Sene East ( New ) & & 55 & 71 & 4.89 & 2.92 & 1.2 & 20.7 & 0.7 & 0.365675 \\
\hline 9. & Asunafo South & & 57 & 81.7 & 4.46 & 2.88 & 1.8 & 33 & 1 & 0.335636 \\
\hline 10. & Jaman North & 1 & NA & 77.5 & 4.36 & 2.79 & 4.2 & 41.8 & 2.2 & 0.267919 \\
\hline 11. & Asutifi South (New) & & 43 & 74 & 4.38 & 2.88 & 3.9 & 46.2 & 3 & 0.261987 \\
\hline 12. & Tano North & 1 & 56 & 65.4 & 4.34 & 2.79 & 3.4 & 43.6 & 2.6 & 0.255935 \\
\hline 13. & Dormaa East & 1 & 41 & 67.6 & 4.28 & 2.79 & 3.3 & 43.1 & 1.7 & 0.237295 \\
\hline 14. & Kintampo South & & NA & 82.6 & 4.38 & 2.85 & 1.5 & 26.5 & 0.9 & 0.217022 \\
\hline 15. & Wenchi Municipal & 1 & NA & 66 & 4.33 & 2.79 & 4.4 & 40.2 & 2.8 & 0.180926 \\
\hline & Mean & - & 92.8 & 74.44 & 4.48 & 2.84 & 3.63 & 35.94 & 2.99 & \\
\hline & Median & - & 93 & 73.2 & 4.38 & 2.81 & 3.3 & 35.1 & 2 & \\
\hline & standard deviation & - & 45.47 & 8.3 & 0.21 & 0.05 & 3.79 & 12.3 & 4.78 & \\
\hline
\end{tabular}


Table 5: Best potential districts of Central region

\begin{tabular}{|c|c|c|c|c|c|c|c|c|c|c|}
\hline 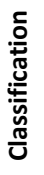 & District & $\begin{array}{l}\text { Rural } \\
\text { banks }\end{array}$ & $\begin{array}{l}\text { Employed } \\
\text { population } \\
\text { in NGOs }\end{array}$ & $\begin{array}{l}\text { Rural non- } \\
\text { electrification } \\
\text { rate } \\
(\%)\end{array}$ & $\begin{array}{l}\text { Annual } \\
\text { average } \\
\text { radiation }\end{array}$ & $\begin{array}{c}\text { Annual } \\
\text { average } \\
\text { wind speed }\end{array}$ & $\begin{array}{c}\text { Desktop/lap } \\
\text { top } \\
\text { computers } \\
\text { owners } \\
\text { (\%) }\end{array}$ & $\begin{array}{c}\text { Mobile } \\
\text { phones } \\
\text { owners } \\
\text { (\%) }\end{array}$ & $\begin{array}{c}\text { Internet } \\
\text { facility users } \\
\text { (\%) }\end{array}$ & $\begin{array}{c}\text { Total average } \\
\text { of normalised } \\
\text { values }\end{array}$ \\
\hline 1. & $\begin{array}{l}\text { Asikuma/ Odoben/ } \\
\text { Brakwa }\end{array}$ & 1 & 125 & 74.6 & 4.58 & 3.67 & 2.8 & 34 & 1.7 & 0.545455 \\
\hline 2. & $\begin{array}{l}\text { Agona West } \\
\text { Municipal }\end{array}$ & 1 & 108 & 71.8 & 4.67 & 3.67 & 6.7 & 50.9 & 6 & 0.487788 \\
\hline 3. & $\begin{array}{l}\text { Upper Denkyira } \\
\text { East Municipal }\end{array}$ & 2 & 58 & 72.9 & 4.6 & 3.49 & 6.3 & 47 & 4.8 & 0.427719 \\
\hline & mean & - & 97 & 73.1 & 4.67 & 3.61 & 5.26 & 43.9 & 4.16 & \\
\hline & median & - & 108 & 72.9 & 4.6 & 3.67 & 6.3 & 47 & 4.8 & \\
\hline & standard deviation & - & 34.8 & 1.41 & 0.04 & 0.10 & 2.14 & 8.84 & 2.21 & \\
\hline
\end{tabular}


Table 6: Best potential districts of Eastern region

\begin{tabular}{|c|c|c|c|c|c|c|c|c|c|c|}
\hline 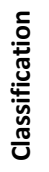 & District & $\begin{array}{l}\text { Rural } \\
\text { banks }\end{array}$ & $\begin{array}{c}\text { Employed } \\
\text { population } \\
\text { in NGOs }\end{array}$ & $\begin{array}{l}\text { Rural non- } \\
\text { electrification } \\
\text { rate } \\
(\%)\end{array}$ & $\begin{array}{l}\text { Annual } \\
\text { average } \\
\text { radiation }\end{array}$ & $\begin{array}{l}\text { Annual } \\
\text { average } \\
\text { wind } \\
\text { speed }\end{array}$ & $\begin{array}{l}\text { Desktop/ } \\
\text { laptop } \\
\text { computers } \\
\text { owners } \\
\text { (\%) }\end{array}$ & $\begin{array}{c}\text { Mobile } \\
\text { phones } \\
\text { owners } \\
(\%)\end{array}$ & $\begin{array}{l}\text { Internet } \\
\text { facility } \\
\text { users } \\
(\%)\end{array}$ & $\begin{array}{c}\text { Total average } \\
\text { of } \\
\text { normalised } \\
\text { values }\end{array}$ \\
\hline 1. & $\begin{array}{l}\text { Afram Plains } \\
\text { South }\end{array}$ & 1 & 104 & 90.2 & 4.74 & 3.25 & 0.9 & 27.1 & 1 & 0.643579 \\
\hline 2. & $\begin{array}{l}\text { Afram Plains } \\
\text { North }\end{array}$ & & 118 & 80.6 & 4.74 & 3.25 & 3.5 & 22.6 & 2.1 & 0.514669 \\
\hline 3. & $\begin{array}{l}\text { Birim Central } \\
\text { Municipal }\end{array}$ & & 94 & 63.4 & 4.51 & 3.67 & 5.6 & 48.1 & 4.4 & 0.374601 \\
\hline 4. & Kwahu East & 2 & 45 & 64.2 & 4.45 & 3.32 & 4.6 & 44.5 & 4.1 & 0.342056 \\
\hline 5. & Ayensuano & & 79 & 67.1 & 4.63 & 3.67 & 0.9 & 31.6 & 1.4 & 0.328912 \\
\hline & mean & - & 88 & 73.1 & 4.61 & 3.43 & 3.1 & 34.78 & 2.6 & \\
\hline & median & - & 94 & 67.1 & 4.63 & 3.32 & 3.5 & 31.6 & 2.1 & \\
\hline & $\begin{array}{l}\text { standard } \\
\text { deviation }\end{array}$ & - & 27.9 & 11.8 & 0.13 & 0.21 & 2.14 & 11.0 & 1.5 & \\
\hline
\end{tabular}


Table 7: Best potential districts of Northern region

\begin{tabular}{|c|c|c|c|c|c|c|c|c|c|c|}
\hline 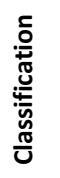 & District & $\begin{array}{l}\text { Rural } \\
\text { banks }\end{array}$ & $\begin{array}{l}\text { Employed } \\
\text { population } \\
\text { in NGOs }\end{array}$ & $\begin{array}{l}\text { Rural non- } \\
\text { electrification } \\
\text { rate } \\
\text { (\%) }\end{array}$ & $\begin{array}{l}\text { Annual } \\
\text { average } \\
\text { radiation }\end{array}$ & $\begin{array}{l}\text { Annual } \\
\text { average } \\
\text { wind } \\
\text { speed }\end{array}$ & $\begin{array}{l}\text { Desktop/ } \\
\text { laptop } \\
\text { computers } \\
\text { owners } \\
\text { (\%) }\end{array}$ & $\begin{array}{c}\text { Mobile } \\
\text { phones } \\
\text { owners } \\
(\%)\end{array}$ & $\begin{array}{c}\text { Internet } \\
\text { facility } \\
\text { users } \\
\text { (\%) }\end{array}$ & $\begin{array}{c}\text { Total } \\
\text { average of } \\
\text { normalised } \\
\text { values }\end{array}$ \\
\hline 1. & Gushiegu & 1 & 252 & 92.9 & 4.61 & 2.89 & 0.5 & 11.9 & 0.5 & 0.807343 \\
\hline 2. & West Mamprusi & 1 & 143 & 82.5 & 4.65 & 2.94 & 1.4 & 20.5 & 0.9 & 0.714116 \\
\hline 3. & $\begin{array}{l}\text { Savelugu/ } \\
\text { Nanton } \\
\text { Municipal }\end{array}$ & 1 & 249 & 64.3 & 4.74 & 2.89 & 1.6 & 25.3 & 1.1 & 0.709937 \\
\hline 4. & Tolon & 1 & 130 & 65.4 & 4.68 & 2.92 & 15.7 & 15.7 & 2.3 & 0.647923 \\
\hline 5. & West Gonja & 1 & 85 & 72.5 & 4.6 & 2.92 & 3.4 & 29.1 & 2.2 & 0.597638 \\
\hline 6. & Zabzugu & 1 & NA & 85 & 4.62 & 2.9 & 0.5 & 14.4 & 0.6 & 0.549394 \\
\hline 7. & East Mamprusi & 1 & NA & 83.1 & 4.55 & 2.94 & 1.4 & 13.9 & 0.8 & 0.546122 \\
\hline 8. & Central Gonja & & 107 & 93.5 & 4.72 & 2.92 & 2.9 & 15.9 & 0.5 & 0.508146 \\
\hline 9. & Chereponi & & 92 & 94.4 & 4.66 & 2.9 & 0.9 & 11 & 0.6 & 0.454324 \\
\hline 10. & $\begin{array}{l}\text { Yendi } \\
\text { Municipal }\end{array}$ & & 135 & 84.7 & 4.59 & 2.89 & 2.3 & 28.2 & 2.2 & 0.440283 \\
\hline 11. & $\begin{array}{l}\text { Sawla-Tuna- } \\
\text { Kalba }\end{array}$ & & 133 & 95.2 & 4.39 & 2.95 & 0.8 & 12.1 & 0.7 & 0.439218 \\
\hline 12. & Tatale Sangule & & 111 & 91 & 4.62 & 2.9 & 0.7 & 11.5 & 0.5 & 0.437721 \\
\hline 13. & North Gonja & & NA & 98.3 & 4.74 & 2.92 & 0.1 & 9.3 & 0.3 & 0.429051 \\
\hline 14. & Saboba & & 90 & 87.3 & 4.69 & 2.9 & 1 & 13.2 & 0.8 & 0.426842 \\
\hline 15. & $\begin{array}{l}\text { Nanumba } \\
\text { North }\end{array}$ & & 180 & 82.4 & 4.67 & 2.8 & 1.4 & 18.7 & 1 & 0.411154 \\
\hline 16. & Mion (New) & & 96 & 92.2 & 4.53 & 2.89 & 0.3 & 12.3 & 1 & 0.395728 \\
\hline 17. & East Gonja & & 160 & 79.9 & 4.74 & 2.8 & 1 & 1 & 0.01 & 0.376452 \\
\hline 18. & Karaga & & 87 & 86.2 & 4.6 & 2.89 & 0.4 & 9.4 & 0.5 & 0.37186 \\
\hline 19. & $\begin{array}{l}\text { Nanumba } \\
\text { South }\end{array}$ & & 118 & 80 & 4.63 & 2.86 & 0.5 & 16 & 0.5 & 0.361427 \\
\hline 20. & Kumbungu & & 110 & 60.7 & 4.7 & 2.89 & 0.5 & 16.9 & 0.7 & 0.293079 \\
\hline 21. & Kpandai & & 122 & 74.9 & 4.62 & 2.8 & 0.6 & 13.7 & 0.5 & 0.288187 \\
\hline & mean & - & 133 & 83.1 & 4.63 & 2.89 & 1.80 & 15.2 & 0.867 & \\
\hline & median & - & 120 & 84.7 & 4.63 & 2.9 & 0.9 & 13.9 & 0.7 & \\
\hline & $\begin{array}{l}\text { standard } \\
\text { deviation }\end{array}$ & - & 49.7 & 10.6 & 0.08 & 0.04 & 3.29 & 6.51 & 0.622 & \\
\hline
\end{tabular}


Table 8: Best potential districts of Upper East region

\begin{tabular}{|c|c|c|c|c|c|c|c|c|c|c|}
\hline$\frac{c}{: 0}$ & District & $\begin{array}{l}\text { Rural } \\
\text { banks }\end{array}$ & $\begin{array}{c}\text { Employed } \\
\text { population } \\
\text { in NGOs }\end{array}$ & $\begin{array}{l}\text { Rural non- } \\
\text { electrification } \\
\text { rate } \\
(\%)\end{array}$ & $\begin{array}{l}\text { Annual } \\
\text { average } \\
\text { radiation }\end{array}$ & $\begin{array}{l}\text { Annual } \\
\text { average } \\
\text { wind } \\
\text { speed }\end{array}$ & $\begin{array}{l}\text { Desktop/ } \\
\text { laptop } \\
\text { computers } \\
\text { owners } \\
(\%)\end{array}$ & $\begin{array}{l}\text { Mobile } \\
\text { phones } \\
\text { owners } \\
(\%)\end{array}$ & $\begin{array}{l}\text { Internet } \\
\text { facility } \\
\text { users } \\
(\%)\end{array}$ & $\begin{array}{c}\text { Total } \\
\text { average of } \\
\text { normalised } \\
\text { values }\end{array}$ \\
\hline 1. & Bongo & 1 & 110 & 91.2 & 4.57 & 2.94 & 1.3 & 24.2 & 2.3 & 0.670208 \\
\hline 2. & $\begin{array}{l}\text { Garu- } \\
\text { Tempane }\end{array}$ & 1 & 149 & 91.4 & 4.49 & 2.94 & 0.9 & 14.7 & 0.6 & 0.624758 \\
\hline 3. & Bawku West & 1 & 108 & 89.2 & 4.52 & 2.94 & 1.3 & 17.6 & 0.9 & 0.595274 \\
\hline 4. & Builsa North & 1 & 81 & 83.7 & 4.68 & 2.86 & 2.2 & 22.1 & 1.7 & 0.511749 \\
\hline 5. & $\begin{array}{l}\text { Bolgatanga } \\
\text { Municipal }\end{array}$ & & 413 & 76.4 & 4.6 & 2.94 & 9.4 & 24.2 & 2.3 & 0.467817 \\
\hline 6. & Talensi & & 102 & 91.6 & 4.62 & 2.94 & 1.1 & 19.4 & 1 & 0.448177 \\
\hline 7. & Binduri & & 102 & 86.5 & 4.58 & 2.94 & 1.4 & 17.3 & 1.1 & 0.350663 \\
\hline 8. & $\begin{array}{l}\text { Kassena } \\
\text { Nankana East }\end{array}$ & & 256 & 84.6 & 4.56 & 2.86 & 5 & 28.2 & 4.7 & 0.345916 \\
\hline 9. & Nabdam & & 40 & 90.8 & 4.51 & 2.94 & 0.8 & 18.9 & 1.6 & 0.32903 \\
\hline 10. & $\begin{array}{l}\text { Bawku } \\
\text { Municipal }\end{array}$ & & 109 & 79 & 4.53 & 2.94 & 3.8 & 37.6 & 2.1 & 0.261608 \\
\hline 11. & Pusiga & & 57 & 80.8 & 4.49 & 2.94 & 1 & 19.4 & 1 & 0.186577 \\
\hline & mean & - & 138 & 85.9 & 4.55 & 2.92 & 2.56 & 22.1 & 1.75 & \\
\hline & median & - & 108 & 86.5 & 4.56 & 2.94 & 1.3 & 19.4 & 1.6 & \\
\hline & $\begin{array}{l}\text { standard } \\
\text { deviation }\end{array}$ & - & 106 & 5.44 & 0.05 & 0.03 & 2.63 & 6.39 & 1.14 & \\
\hline
\end{tabular}


Table 9: Best potential districts of Upper West region

\begin{tabular}{|c|c|c|c|c|c|c|c|c|c|c|}
\hline 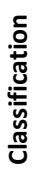 & District & $\begin{array}{l}\text { Rural } \\
\text { banks }\end{array}$ & $\begin{array}{l}\text { Employed } \\
\text { population } \\
\text { in NGOs }\end{array}$ & $\begin{array}{l}\text { Rural non- } \\
\text { electrification } \\
\text { rate } \\
\text { (\%) }\end{array}$ & $\begin{array}{c}\text { Annual } \\
\text { average } \\
\text { radiation }\end{array}$ & $\begin{array}{c}\text { Annual } \\
\text { average } \\
\text { wind } \\
\text { speed }\end{array}$ & $\begin{array}{l}\text { Desktop/ } \\
\text { laptop } \\
\text { computers } \\
\text { owners } \\
\text { (\%) }\end{array}$ & $\begin{array}{c}\text { Mobile phones } \\
\text { owners } \\
\text { (\%) }\end{array}$ & $\begin{array}{l}\text { Internet } \\
\text { facility } \\
\text { users } \\
(\%)\end{array}$ & $\begin{array}{c}\text { Total average } \\
\text { of normalised } \\
\text { values }\end{array}$ \\
\hline 1. & Jirapa & 1 & 136 & 90.7 & 4.47 & 2.79 & 2.4 & 15.9 & 1.2 & 0.76522 \\
\hline 2. & Wa East & & 99 & 90.1 & 4.57 & 2.92 & 0.3 & 10.3 & 0.3 & 0.596236 \\
\hline 3. & Sissala East & 1 & 107 & 76 & 4.46 & 2.86 & 3.5 & 21 & 1.4 & 0.586088 \\
\hline 4. & Lawra & 1 & 102 & 78.9 & 4.46 & 2.79 & 2 & 19.3 & 1.1 & 0.532819 \\
\hline 5. & Nandom & 1 & NA & 81.6 & 4.44 & 2.79 & 2 & 21 & 1.7 & 0.393722 \\
\hline 6. & $\begin{array}{l}\text { Lambussie } \\
\text { Karni }\end{array}$ & & 92 & 86.2 & 4.46 & 2.79 & 2.4 & 19.4 & 1 & 0.383193 \\
\hline 7. & Nadowli Kaleo & & 82 & 75.9 & 4.52 & 2.79 & 2.4 & 19.9 & 1.4 & 0.280546 \\
\hline 8. & $\begin{array}{l}\text { Daffiama } \\
\text { Bussie Issa }\end{array}$ & & 39 & 78 & 4.44 & 2.79 & 1.3 & 18.9 & 1.2 & 0.143573 \\
\hline & Mean & - & 93.8 & 82.1 & 4.47 & 2.815 & 2.03 & 18.2 & 1.16 & \\
\hline & median & - & 99 & 80.25 & 4.46 & 2.79 & 2.2 & 19.35 & 1.2 & \\
\hline & $\begin{array}{l}\text { standard } \\
\text { deviation }\end{array}$ & - & 29.4 & 6.06 & 0.04 & 0.04 & 0.93 & 3.57 & 0.41 & \\
\hline
\end{tabular}


Table 10: Best potential districts of Volta region

\begin{tabular}{|c|c|c|c|c|c|c|c|c|c|c|}
\hline 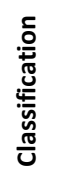 & District & $\begin{array}{l}\text { Rural } \\
\text { banks }\end{array}$ & $\begin{array}{c}\text { Employed } \\
\text { population } \\
\text { in NGOs }\end{array}$ & $\begin{array}{l}\text { Rural non- } \\
\text { electrification } \\
\text { rate } \\
(\%)\end{array}$ & $\begin{array}{c}\text { Annual } \\
\text { average } \\
\text { radiation }\end{array}$ & $\begin{array}{l}\text { Annual } \\
\text { average } \\
\text { wind } \\
\text { speed }\end{array}$ & $\begin{array}{l}\text { Desktop/ } \\
\text { laptop } \\
\text { computers } \\
\text { owners } \\
\text { (\%) }\end{array}$ & $\begin{array}{c}\text { Mobile } \\
\text { phones } \\
\text { owners } \\
\text { (\%) }\end{array}$ & $\begin{array}{c}\text { Internet } \\
\text { facility } \\
\text { users } \\
(\%)\end{array}$ & $\begin{array}{c}\text { Total average } \\
\text { of normalised } \\
\text { values }\end{array}$ \\
\hline 1. & Akatsi South & 1 & 115 & 75 & 4.79 & 3.48 & 1.7 & 36.5 & 2 & 0.683427 \\
\hline 2. & $\begin{array}{l}\text { Ketu South } \\
\text { Municipal }\end{array}$ & & 213 & 78.1 & 5.06 & 3.77 & 2.4 & 45.8 & 4 & 0.675397 \\
\hline 3. & South Tongu & 1 & 164 & 66.4 & 4.88 & 3.48 & 2.7 & 39.4 & 3 & 0.668431 \\
\hline 4. & Nkwanta South & 1 & 160 & 80.2 & 4.33 & 2.86 & 1.5 & 21.3 & 1 & 0.648515 \\
\hline 5. & North Tongu & 1 & NA & 79.3 & 4.8 & 3.48 & 2.4 & 37.3 & 50 & 0.645243 \\
\hline 6. & Agotime Ziope & 1 & 80 & 69.4 & 4.75 & 3.48 & 2.3 & 36.7 & 2.5 & 0.585736 \\
\hline 7. & Keta Municipal & 1 & NA & 66 & 5.22 & 3.87 & 2.9 & 41.9 & 6 & 0.581665 \\
\hline 8. & Central Tongu & 1 & 80 & 68 & 4.89 & 3.48 & 1.6 & 35.3 & 1.8 & 0.570751 \\
\hline 9. & Ketu North & & 154 & 77.1 & 4.72 & 3.48 & 1.4 & 36.9 & 1.7 & 0.492561 \\
\hline 10. & Krachi East & & 158 & 69.5 & 4.79 & 3.06 & 1.3 & 22 & 1 & 0.352468 \\
\hline 11. & Biakoye & & 142 & 62.8 & 4.55 & 3.49 & 1.3 & 31.5 & 1.6 & 0.274825 \\
\hline 12. & Krachi West & & 72 & 68.7 & 4.93 & 2.92 & 1.5 & 24.8 & 1.4 & 0.263833 \\
\hline 13. & $\begin{array}{l}\text { Krachi } \\
\text { Nchumuru }\end{array}$ & & 103 & 63.2 & 4.64 & 2.8 & 0.8 & 19.6 & 0.4 & 0.156998 \\
\hline & mean & - & 131 & 71.0 & 4.79 & 3.35 & 1.83 & 33 & 5.87 & \\
\hline & median & - & 142 & 69.4 & 4.79 & 3.48 & 1.6 & 36.5 & 1.8 & \\
\hline & $\begin{array}{l}\text { standard } \\
\text { deviation }\end{array}$ & - & 44.4 & 6.12 & 0.22 & 0.33 & 0.63 & 8.44 & 13.3 & \\
\hline
\end{tabular}


Table 11: Best potential districts of Western region

\begin{tabular}{|c|c|c|c|c|c|c|c|c|c|c|}
\hline 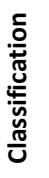 & District & $\begin{array}{l}\text { Rural } \\
\text { banks }\end{array}$ & $\begin{array}{l}\text { Employed } \\
\text { population } \\
\text { in NGOs }\end{array}$ & $\begin{array}{l}\text { Rural non- } \\
\text { electrification } \\
\text { rate } \\
\text { (\%) }\end{array}$ & $\begin{array}{c}\text { Annual } \\
\text { average } \\
\text { radiation }\end{array}$ & $\begin{array}{l}\text { Annual } \\
\text { average } \\
\text { wind } \\
\text { speed }\end{array}$ & $\begin{array}{l}\text { Desktop/ } \\
\text { laptop } \\
\text { computers } \\
\text { owners } \\
\text { (\%) }\end{array}$ & $\begin{array}{c}\text { Mobile } \\
\text { phones } \\
\text { owners } \\
(\%)\end{array}$ & $\begin{array}{l}\text { Internet } \\
\text { facility } \\
\text { users } \\
(\%)\end{array}$ & $\begin{array}{c}\text { Total } \\
\text { average of } \\
\text { normalised } \\
\text { values }\end{array}$ \\
\hline 1. & Bia West & 1 & 132 & 83.1 & 4.54 & 3.07 & 1.8 & 42.9 & 1.5 & 0.823223 \\
\hline 2. & Amenfi Central & 1 & 104 & 62.6 & 4.56 & 3.32 & 1.4 & NA & NA & 0.61049 \\
\hline 3. & Wassa East & 1 & 88 & 67.3 & 4.47 & 3.49 & 2.3 & 29 & 1.4 & 0.610203 \\
\hline 4. & Amenfi West & & 160 & 77.6 & 4.49 & 3.32 & 3 & 39.9 & 1.4 & 0.576777 \\
\hline 5. & $\begin{array}{l}\text { Nzema East } \\
\text { Municipal }\end{array}$ & 1 & 103 & 61.9 & 4.42 & 3.32 & 2.7 & 32.1 & 2.8 & 0.513297 \\
\hline 6. & Sefwi Akontombra & & 94 & 82.3 & 4.48 & 2.88 & 1.4 & 34.3 & 0.8 & 0.42653 \\
\hline 7. & Suaman & & 47 & 77.7 & 4.51 & 2.84 & 3.9 & 40.4 & 1.4 & 0.367895 \\
\hline 8. & Juaboso & & 114 & 64.7 & 4.53 & 2.88 & 2.5 & 46.5 & 1.4 & 0.342033 \\
\hline \multirow[t]{4}{*}{9.} & Aowin & & NA & 65.8 & 4.49 & 3.32 & 0.31 & 63.2 & 71.7 & 0.223405 \\
\hline & mean & - & 105 & 71.4 & 4.49 & 3.16 & 2.14 & 41.0 & 10.3 & \\
\hline & median & - & 103 & 67.3 & 4.49 & 3.32 & 2.3 & 40.15 & 1.4 & \\
\hline & $\begin{array}{l}\text { standard } \\
\text { deviation }\end{array}$ & - & 32.9 & 8.62 & 0.04 & 0.24 & 1.05 & 10.6 & 24.8 & \\
\hline
\end{tabular}


Table 12: Forty five first districts ranked by mean score

\begin{tabular}{|c|c|c|c|c|c|c|c|c|c|c|c|}
\hline 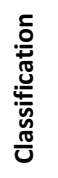 & District & $\begin{array}{l}\text { Rural } \\
\text { banks }\end{array}$ & $\begin{array}{l}\text { Employed } \\
\text { population } \\
\text { in NGOs }\end{array}$ & $\begin{array}{l}\text { Rural un- } \\
\text { electrificati } \\
\text { on rate } \\
\text { (\%) }\end{array}$ & $\begin{array}{c}\text { Annual } \\
\text { average } \\
\text { radiation }\end{array}$ & $\begin{array}{l}\text { Annual } \\
\text { average } \\
\text { wind } \\
\text { speed }\end{array}$ & $\begin{array}{l}\text { Desktop/ } \\
\text { laptop } \\
\text { computer } \\
\text { s owners } \\
\text { (\%) }\end{array}$ & $\begin{array}{c}\text { Mobile } \\
\text { phones } \\
\text { owners } \\
\text { (\%) }\end{array}$ & $\begin{array}{c}\text { Internet } \\
\text { facility } \\
\text { users } \\
(\%)\end{array}$ & $\begin{array}{c}\text { Total } \\
\text { average of } \\
\text { normalised } \\
\text { values }\end{array}$ & Region \\
\hline 1. & Gushiegu & 1 & 252 & 92.9 & 4.61 & 2.89 & 0.5 & 11.9 & 0.5 & 0.500582 & Northern \\
\hline 2. & $\begin{array}{l}\text { Upper Denkyira } \\
\text { East Municipal }\end{array}$ & 2 & 58 & 72.9 & 4.6 & 3.49 & 6.3 & 47 & 4.8 & 0.492745 & Central \\
\hline 3. & Afram Plains South & 1 & 104 & 90.2 & 4.74 & 3.25 & 0.9 & 27.1 & 1 & 0.464203 & Eastern \\
\hline 4. & $\begin{array}{l}\text { Ketu South } \\
\text { Municipal }\end{array}$ & & 213 & 78.1 & 5.06 & 3.77 & 2.4 & 45.8 & 4 & 0.440368 & Volta \\
\hline 5. & Adansi South & 1 & 119 & 81.1 & 4.69 & 3.48 & 1.3 & 29 & 1.4 & 0.439311 & Ashanti \\
\hline 6. & $\begin{array}{l}\text { Ejura/ } \\
\text { Sekyedumase } \\
\text { Municipal }\end{array}$ & 2 & 86 & 71.7 & 4.64 & 2.85 & 3.1 & 39.2 & 3 & 0.430967 & Ashanti \\
\hline 7. & Garu-Tempane & 1 & 149 & 91.4 & 4.49 & 2.94 & 0.9 & 14.7 & 0.6 & 0.427278 & $\begin{array}{l}\text { Upper } \\
\text { East }\end{array}$ \\
\hline 8. & $\begin{array}{l}\text { Agona West } \\
\text { Municipal }\end{array}$ & 1 & 108 & 71.8 & 4.67 & 3.67 & 6.7 & 50.9 & 6 & 0.422685 & Central \\
\hline 9 & Bongo & 1 & 110 & 91.2 & 4.57 & 2.94 & 1.3 & 24.2 & 2.3 & 0.42082 & $\begin{array}{l}\text { Upper } \\
\text { East }\end{array}$ \\
\hline 10. & Akatsi South & 1 & 115 & 75 & 4.79 & 3.48 & 1.7 & 36.5 & 2 & 0.420257 & Volta \\
\hline 11. & $\begin{array}{l}\text { Asikuma/ Odoben/ } \\
\text { Brakwa }\end{array}$ & 1 & 125 & 74.6 & 4.58 & 3.67 & 2.8 & 34 & 1.7 & 0.416884 & Central \\
\hline 12. & South Tongu & 1 & 164 & 66.4 & 4.88 & 3.48 & 2.7 & 39.4 & 3 & 0.414591 & Volta \\
\hline 13. & $\begin{array}{l}\text { Bolgatanga } \\
\text { Municipal }\end{array}$ & & 413 & 76.4 & 4.6 & 2.94 & 9.4 & 24.2 & 2.3 & 0.408902 & $\begin{array}{l}\text { Upper } \\
\text { East }\end{array}$ \\
\hline 14. & Keta Municipal & 1 & NA & 66 & 5.22 & 3.87 & 2.9 & 41.9 & 6 & 0.406558 & Volta \\
\hline 15 & Bia West & 1 & 132 & 83.1 & 4.54 & 3.07 & 1.8 & 42.9 & 1.5 & 0.405914 & Western \\
\hline 16. & Jirapa & 1 & 136 & 90.7 & 4.47 & 2.79 & 2.4 & 15.9 & 1.2 & 0.40365 & $\begin{array}{l}\text { Upper } \\
\text { West }\end{array}$ \\
\hline 17. & Bawku West & 1 & 108 & 89.2 & 4.52 & 2.94 & 1.3 & 17.6 & 0.9 & 0.398663 & $\begin{array}{l}\text { Upper } \\
\text { East }\end{array}$ \\
\hline 18. & West Mamprusi & 1 & 143 & 82.5 & 4.65 & 2.94 & 1.4 & 20.5 & 0.9 & 0.398494 & Northern \\
\hline 19. & Pru & 1 & 132 & 84.7 & 4.7 & 2.8 & 0.8 & 20 & 0.5 & 0.395594 & $\begin{array}{l}\text { Brong } \\
\text { Hahafo }\end{array}$ \\
\hline 20. & North Tongu & 1 & NA & 79.3 & 4.8 & 3.48 & 2.4 & 37.3 & 50 & 0.394949 & Volta \\
\hline 21. & Kwahu East & 2 & 45 & 64.2 & 4.45 & 3.32 & 4.6 & 44.5 & 4.1 & 0.394523 & Eastern \\
\hline 22. & Central Tongu & 1 & 80 & 68 & 4.89 & 3.48 & 1.6 & 35.3 & 1.8 & 0.373534 & Volta \\
\hline 23. & Atebubu-Amantin & 1 & 104 & 78.1 & 4.76 & 2.92 & 2.8 & 29.5 & 2 & 0.372628 & $\begin{array}{l}\text { Brong } \\
\text { Hahafo }\end{array}$ \\
\hline 24. & Builsa North & 1 & 81 & 83.7 & 4.68 & 2.86 & 2.2 & 22.1 & 1.7 & 0.370252 & $\begin{array}{l}\text { Upper } \\
\text { East }\end{array}$ \\
\hline 25 & Agotime Ziope & 1 & 80 & 69.4 & 4.75 & 3.48 & 2.3 & 36.7 & 2.5 & 0.366087 & Volta \\
\hline 26. & $\begin{array}{l}\text { Savelugu/ Nanton } \\
\text { Municipal }\end{array}$ & 1 & 249 & 64.3 & 4.74 & 2.89 & 1.6 & 25.3 & 1.1 & 0.363639 & Northern \\
\hline 27. & Tain & 2 & 120 & 62.6 & 4.42 & 2.81 & 2.4 & 35.1 & 1 & 0.361821 & $\begin{array}{l}\text { Brong } \\
\text { Hahafo }\end{array}$ \\
\hline 28. & Nkwanta South & 1 & 160 & 80.2 & 4.33 & 2.86 & 1.5 & 21.3 & 1 & 0.346416 & Volta \\
\hline 29. & Atwima Mponua & 1 & 156 & 80.3 & 4.3 & 2.88 & 1.1 & 30.9 & 1.1 & 0.346208 & Ashanti \\
\hline 30. & $\begin{array}{l}\text { Kassena Nankana } \\
\text { East }\end{array}$ & & 256 & 84.6 & 4.56 & 2.86 & 5 & 28.2 & 4.7 & 0.346047 & $\begin{array}{l}\text { Upper } \\
\text { East }\end{array}$ \\
\hline 31. & $\begin{array}{l}\text { Kintampo } \\
\text { Municipal }\end{array}$ & 1 & NA & 92.7 & 4.38 & 2.8 & 3.4 & 33.9 & 2.5 & 0.340747 & $\begin{array}{l}\text { Brong } \\
\text { Hahafo }\end{array}$ \\
\hline 32 & Sunyani Municipal & 1 & 157 & 68.5 & 4.31 & 2.79 & 16.7 & 66 & 20 & 0.335465 & $\begin{array}{l}\text { Brong } \\
\text { Hahafo }\end{array}$ \\
\hline 33. & Tolon & 1 & 130 & 65.4 & 4.68 & 2.92 & 15.7 & 15.7 & 2.3 & 0.334023 & Northern \\
\hline 34 & Central Gonja & & 107 & 93.5 & 4.72 & 2.92 & 2.9 & 15.9 & 0.5 & 0.328501 & Northern \\
\hline 35. & Ketu North & & 154 & 77.1 & 4.72 & 3.48 & 1.4 & 36.9 & 1.7 & 0.322626 & Volta \\
\hline 36. & Zabzugu & 1 & NA & 85 & 4.62 & 2.9 & 0.5 & 14.4 & 0.6 & 0.32078 & Northern \\
\hline
\end{tabular}




\begin{tabular}{|c|c|c|c|c|c|c|c|c|c|c|c|}
\hline 37. & Wassa East & 1 & 88 & 67.3 & 4.47 & 3.49 & 2.3 & 29 & 1.4 & 0.319751 & Western \\
\hline 38. & Lawra & 1 & 102 & 78.9 & 4.46 & 2.79 & 2 & 19.3 & 1.1 & 0.317525 & $\begin{array}{l}\text { Upper } \\
\text { West }\end{array}$ \\
\hline 39. & Sissala East & 1 & 107 & 76 & 4.46 & 2.86 & 3.5 & 21 & 1.4 & 0.315742 & $\begin{array}{l}\text { Upper } \\
\text { West }\end{array}$ \\
\hline 40. & West Gonja & 1 & 85 & 72.5 & 4.6 & 2.92 & 3.4 & 29.1 & 2.2 & 0.31145 & Northern \\
\hline 41. & Chereponi & & 92 & 94.4 & 4.66 & 2.9 & 0.9 & 11 & 0.6 & 0.307918 & Northern \\
\hline 42. & East Mamprusi & 1 & NA & 83.1 & 4.55 & 2.94 & 1.4 & 13.9 & 0.8 & 0.30724 & Northern \\
\hline 43. & Sawla-Tuna-Kalba & & 133 & 95.2 & 4.39 & 2.95 & 0.8 & 12.1 & 0.7 & 0.305339 & Northern \\
\hline 44 & Afram Plains North & & 118 & 80.6 & 4.74 & 3.25 & 3.5 & 22.6 & 2.1 & 0.301822 & Eastern \\
\hline 45. & Talensi & & 102 & 91.6 & 4.62 & 2.94 & 1.1 & 19.4 & 1 & 0.300883 & $\begin{array}{l}\text { Upper } \\
\text { East }\end{array}$ \\
\hline
\end{tabular}


Table 13: Classification of regions

\begin{tabular}{ccc}
\hline Rank & Region & $\begin{array}{c}\text { Number of district in } \\
\text { the classification }\end{array}$ \\
\hline $\mathbf{1 .}$ & Northern & 10 \\
$\mathbf{2}$. & Volta & 9 \\
$\mathbf{3 .}$ & Upper East & 7 \\
$\mathbf{4 .}$ & Brong Hahafo & 4 \\
$\mathbf{5 .}$ & Ashanti & 3 \\
$\mathbf{6 .}$ & Central & 3 \\
$\mathbf{7 .}$ & Eastern & 3 \\
$\mathbf{8 .}$ & Western & 2 \\
/ & Greater Accra & $/$ \\
/ & Upper West & $/$ \\
\hline
\end{tabular}

